\title{
On the Alga-Flora of some Desiccated English Soils: an Important Factor in Soil Biology.
}

\author{
BY \\ B. MURIEL BRISTOL, M.Sc. \\ SYNOPSIS
}

With Plate II and twelve Figures and three Tables in the Text.

I. INTKODUCTION • • • • • • • • • • • . • • •

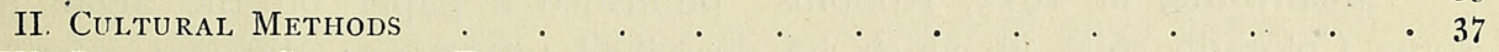

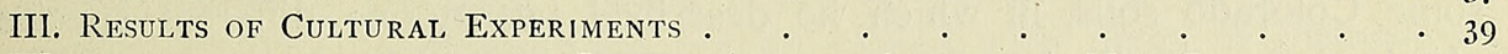

IV. Discussion of the Possible Significance of Algae and Moss Protonema in

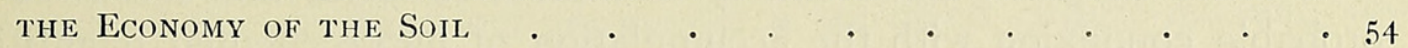

V. Descriptive Notes on the Species found . . . . . . . . . . $\quad$. 59

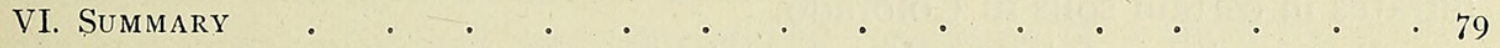

\section{INTRODUCTION.}

URING recent years a good deal of attention has been paid to the activities of certain soil-organisms, with regard to their significance in the economy of the soil. Proceeding from the wonderful discoveries of Pasteur on bacterial fermentation, Berthelot in 1885 established the fact that the building up of nitrates in the soil is due to the activities of certain micro-organisms. This discovery led to wider experiments in all directions, and especially to the investigations of Hellriegel and Wilfarth in connexion with the nitrogen supply of leguminous plants, and of Winogradsky and Beijerinck on the work of nitrogen-fixing bacteria in the soil.

These activities mark the beginning of a new era in biology, and have led to the establishment of a special branch of the science, soil biology, dealing with problems of interest not only to biologists but also to practical agriculturists. The activities of the nitrogen-bacteria of the soil are now well established, while those of the attendant soil-protozoa have already received a considerable amount of attention; and the pathogenic effect on higher plants of nematodes, myxomycetes, bacteria, and fungi occurring in soils is studied as a special branch of plant pathology. The algae of soils have, on the contrary, possibly on account of their supposed lack of importance as factors in the economy of the soil, been almost entirely over-

[Annals of Botany, Vol, XXXIV, No. CXXXIII. January, 1920.]

D 2 
looked, and, in this country at any rate, no systematic work has so far been done in connexion with them. This is all the more extraordinary since the researches of Kossowitsch, Bouilhac, Giustiniani, Schloesing, Laurent, and others clearly indicate that there is an intimate connexion in the soil between algae and the nitrogen-fixing bacteria, and that algae probably play quite a prominent part in the activities carried on by these organisms.

In I910 Esmarch ${ }^{1}$ published a paper on the blue-green algae of the soils of the German African colonies, and as a result of his experiments he concluded that cultivated soils are throughout richer in blue-green algae than are uncultivated soils, and that in cultivated soils algae occur not only in the surface but also in the lower layers. As a consequence of this work he further undertook an investigation of the distribution of the blue-green algae in different soils of Schleswig-Holstein ${ }^{2}$ for the purpose of finding out not only what species are present in different kinds of soil, but also the depths to which they may be found and the possible reasons for their occurrence in such positions.

Meanwhile, in 1912, Robbins ${ }^{3}$ published a paper on the algae in some Colorado soils, in which he described twenty-one different species obtained from cultures of twenty-two different soils, and discussed their probable connexion with the accumulation of unprecedented quantities of nitrates in certain soils in Colorado.

Petersen's work ${ }^{4}$ on the sub-aerial algae of Denmark is a valuable contribution to our knowledge of soil-algae, especially in so far as it concerns soil-diatoms; but his investigations of the green algae appear to have been confined to forms visible on collection to the naked eye, and his lists can therefore scarcely be regarded as exhaustive in this direction. His omission of all reference to blue-green algae also makes it difficult to realize a true conception of the nature and extent of the algal flora of the soils.

In the course of an investigation of soil-protozoa, Dr. T. Goodey and Dr. H. B. Hutchinson recently obtained certain algal forms from old stored soils and sent them to Professor G. S. West for identification. This was impossible at first, but after an investigation extending over several months Professor West was enabled to state that spores of Nodularia Harveyana, (Thwaites) Thuret, are able to retain their vitality for a period of sixty-six years. ${ }^{5} \quad$ This discovery led him to suggest that the study of a number of dried soils by means of cultures might be a profitable one in ascertaining

1 Esmarch, F.: Beitrag zur Cyanophyceen-Flora unserer Kolonien. Jahrbuch der Hamburgischen wissensch. Anstalten, xxviii, 3. Beiheft, S. 62-82, I9IO.

${ }^{2}$ Esmarch, F.: Untersuchungen über die Verbreitung der Cyanophyceen auf und in verschiedenen Boden. Hedwigia, Band lv, Heft 4-5, September 19I4.

${ }^{3}$ Robbins, W. W. : Algae in some Colorado Soils. Bulletin 184, Agr. Exp. Sta. Colorado, June, I9I 2

${ }_{4}$ Petersen, J. B. : Danske aerofile alger. D. Kgl. Danske Vidensk. Selsk. Skrifter, 7 Række, Naturv. og Mathem., Afd. xii, 7 , I9I5.

5 Vide West, G, S. : Algae. I Camb. Bot. Handbooks, p. 28, I9I6. 
whether in this country there exist many algae that are sufficiently resistant to desiccation to be able to persist in the soil during any period of drought that might naturally occur. The investigation was begun in September, 19I5, when a collection was made of small samples of cultivated soils from different parts of the country. The samples were taken from arable land or from old gardens, in such places as appeared to be destitute of vegetation, and were then spread out to dry gradually in a warm room for at least a month, care being taken to prevent foreign infection of the soils by covering them with sterile paper. This preliminary drying of the soils served to kill off any algae present that might be unable to resist prolonged desiccation and to induce any more resistant ones to enter into a resting state. When completely dry, the soil-samples were placed in small tin boxes for storage; by this time the soil in almost every case had crumbled into a fairly fine powder.

\section{Cultural Methods.}

Three cultures of each sample were made, with the exception of Nos. 5 and $35-40$, of which there were only two. The cultures were set up in very carefully sterilized ${ }^{1}$ vessels which comprised glass boxes and small conical flasks or wide-mouthed bottles closed with plugs of cotton-wool. Into each of the sterilized culture-vessels a sterilized culture-medium was introduced to a depth of about half an inch, and into this a few grammes of the soil to be examined were introduced by means of a sterilized spatula. The vessels were closed and placed under glass cases in a north window and left for some months to develop.

The culture-solution most generally used was an aqueous mineral-salt solution having the following composition: $\mathrm{I}$ grm. $\mathrm{KH}_{2} \mathrm{PO}_{4}$, I grm. $\mathrm{NaNO}_{3}$, 0.3 grm. $\mathrm{MgSO}_{4}, 0 \cdot 1 \mathrm{grm} . \mathrm{CaCl}_{2}$, O.I grm. $\mathrm{NaCl}$, a trace of $\mathrm{FeCl}_{3}$, I,, 00 c.c. distilled water.

But for the sake of comparison certain of the cultures were made with a solution diluted with distilled water to half the above strength, and others with sterilized rain-water. Evaporation from the surface of the cultures took place only slowly, and it was found sufficient, in order to keep them moist, to water them at the end of about six months with sterilized distilled water or with rain-water; in one or two cases where the cultures were assuming a brownish colour diluted mineral-salt solution was added.

The first signs of growth were observed in the cultures at about the end of November, when a thin white scum gradually appeared on the surface of the liquid, and was found on examination to consist of bacteria. About six weeks later the scum began to assume a green tinge of colour, and small tufts of green filaments were observed to be growing from the soil at the

1 All the culture-vessels were heated on three separate occasions to a temperature of about $\mathrm{I}_{2} \mathrm{O}^{\circ} \mathrm{C}$., and kept at that temperature for three hours on each occasion. The culture-media were heated in a steam sterilizer for about three hours on each of three occasions. 
bottom of the culture. Owing to the preliminary drying of the soil the cultures for some time contained only developmental stages of algae, and a considerable period elapsed before their identification could be accomplished; but it was easily seen that the green tufts consisted of filaments of moss protonema. At first only green algae and diatoms appeared to be growing in the cultures, forming a stratum on the surface of the liquid and on the sides of the culture-vessel, while the whole liquid assumed a light green colour owing to the presence of free floating unicells. Later, however, patches of blue-green algae began to appear on the surface of the soil and on the glass sides of the vessel below the surface of the water.

Esmarch and Robbins in their investigations adopted rather different methods of culture from the above, but in neither case did the algae grow under quite natural conditions. Esmarch used Petri dishes about $2 \mathrm{~cm}$. deep, in which he kept thoroughly moistened a layer of the soil to be examined; on the surface of the soil he placed a piece of chemically pure filter-paper which was kept in close contact with the soil by constantly smoothing it out with a sterilized iron spatula. He found that the bluegreen algae in the soil germinated and grew towards the light through the pores of the filter-paper and produced strata of various forms on the upper surface of the paper. He observed that green algae and moss protonema also grew occasionally, but very rarely in sufficient quantity to affect the culture to any extent. His result is thus quite different from that obtained in the present work, and unless the prolific growth of green algae in the cultures of English soils is to be regarded as a peculiar characteristic of the soils of this country, it appears rather as though the presence of the filterpaper in Esmarch's cultures tended to suppress the growth of green algae or at any rate to prevent their penetration to the surface of the culture. Of diatoms Esmarch makes no mention, and it is probable that if they were present in the soils they never penetrated the filter-paper and so were completely overlooked.

Robbins for his cultures used half-litre flasks filled to their greatest diameter with washed and sterilized moist ground quartz, on the surface of which was distributed as evenly as possible $10 \mathrm{grm}$. of the soil to be examined suspended in 25 c.c. of distilled water. The flasks were tilted to one side so as to provide both a moist sand and a free water surface for the algae to grow on. In this way the algae were set to grow on a medium the physical qualities of which were quite different from those of the original soil in that all organic substance had been extracted from the quartz before use; also the addition merely of distilled water without any dissolved mineral salts must have caused the algae to be subjected to a somewhat inadequate food supply, in view of the large quantity of insoluble sand present in proportion to the small amount of soluble salts in the inoculated soil. 
It is conspicuous that of twenty-one different species obtained by Robbins from the Colorado soils only one belonged to the diatoms and one to the green algae; the rest all belonged to the blue-green algae.

Petersen, on the other hand, found in cultivated Danish soils no less than twenty different species of diatoms and eighteen different species of green algae, a result very similar to that obtained in the present work, hence it appears from Robbins's record that the Colorado soils may be peculiar in this respect.

A comparison of the results obtained with the different culture-solutions used in the present work showed that there was very little difference between the cultures. Germination of the green algae and diatoms took place rather more quickly in the more dilute mineral-salt solution and in rainwater, while the development of the blue-green algae was on the whole more vigorous in the stronger mineral-salt solution; rain-water appeared as a rule to favour especially the development of the green algae. In every case, however, the final results were identical, cultures of the same soil giving always the same record of species present, whichever culture-medium might be used.

\section{Results of Cultural Experiments.}

A great deal of difficulty was experienced in identifying the algae found in the cultures for various reasons. In the first place, the preliminary treatment of the soils was such as to preclude the possibility of the presence of any algae except in a resting condition in the initial stages of the cultures. The length of time taken for the germination of these resting forms varied in individual species, and for some months the cultures contained largely developmental stages which it was impossible to identify with any degree of certainty. Again, the somewhat abnormal conditions of excessive moisture under which the algae were growing tended to produce forms which in some cases were rather different from those of typical species already described, and it was necessary to decide whether such variations were the result of these conditions or whether they might perhaps characterize new species or varieties. Further, it was necessary in many cases to follow out the complete life-history of the alga before coming to any decision, and for this purpose it was sometimes necessary to prepare sub-cultures in order to separate the alga in question from the other species in the culture. This was especially the case for the species Chlorococcum humicola, (Naeg.) Rabenh., the complete isolation of which was effected by picking out individual cells under the microscope with fine glass capillary tubes and placing them in hanging-drop cultures in a damp chamber. It was found that the algae rarely lived very long in these conditions, but sufficient evidence was obtained to establish the course of the life-history of the species.

In identifying the diatoms various methods were attempted, but the 
dimensions of the species present were so small that only one method proved really satisfactory. In this the material to be examined was placed in water on a glass slide and broken up into very small pieces with a pair of needles; the water was then allowed to evaporate slowly in the air, the slide being covered with a glass lid to prevent the access of dust. The material thus became dried on to the slide and could be subjected to further treatment with little risk of loss. After 24 hours' drying, the slide was placed in a boiling-tube containing strong nitric acid and heated to remove all organic matter; after careful washing in water it was transferred through 95 per cent. and absolute alcohol to xylol, and the film of diatoms still remaining attached to the slide was then mounted in Canada balsam. Owing to the minute size of most of these soil-diatoms the markings on the walls were extremely difficult to make out, even under a magnification of $\mathrm{I}, 435$, hence later preparations were made using dammar lac as a mounting medium in order to secure a better definition of the walls.

The accompanying Tables I, II, and III give full particulars of the experimental details and serve for a comparison of the results obtained from the different cultures. An examination of these results leads to several interesting conclusions in relation to the distribution of algae in the soils examined; and in this connexion it may be mentioned that though taxonomically it belongs to a different group of plants, the protonema of mosses has been included with the soil-algae in considering the possible economic significance of the microscopic green plants of the soil, since its form and mode of growth render it physiologically equivalent to them.

It is easily seen that in a large majority of the soil-samples there is a central group of algae comprising most or all of the following species: Hantzschia amphioxys, Trochiscia aspera, Chlorococcum humicola, Bumilleria exilis, and less often Ulothrix subtilis, var. variabilis, together with moss protonema. These species thus appear to form the basis of an extensive ecological plant-formation in which, by the inclusion of other typically terrestrial but less widely spread species, smaller plant-associations can be recognized. In certain of the soils associations consisting very largely of diatoms are present, the species most generally found being Navicula mutica formae, $N$. Atomus, $N$. contenta, var. biceps, $N$. Balfouriana, $N$. Brebissonii, var. diminuta, $N$. Pupula, and to a lesser degree $N$. borealis. It is conspicuous that with the exception of Navicula borealis, Hantzschia amphioxys, and Nitzschia obtusa, var. scalpelliformis, all the diatoms found in these soils are of very minute size, and it is no doubt this characteristic which enables them to withstand the conditions of drought to which the organisms of the soil are liable to be subjected; since, as has been pointed out by Hedlund, ${ }^{1}$ small organisms seem to be better able to resist desiccation than are larger ones. Even in the cases of the larger species

1 Hedlund, T. : Till frågan om växternas frosthärdighet. Botanisker Notiser, Lund, I9I3. 
mentioned the forms met with from these soils are small in comparison with other forms and varieties of the same species occurring in aquatic habitats. These facts are also true for the diatoms described by Petersen from the Danish soils. He suggests that since the species belong to the pennate diatoms they are further adapted to their mode of life by their power of locomotion, so that they are enabled to move in times of drought to the moister layers of the soil.

In a recent lefter to Professor G. S. West, Dr. A. Mann, of the U.S. Dept. of Agriculture, has suggested that the exceedingly small size of these diatoms, especially of Navicula contenta, var. biceps, is due to long starvation under unfavourablebiological conditions, and that they are merely forms of some of the larger species which have undergone not only reduction in size but also suppression in the sharpness of their markings; he suggests that Navicula contenta is either a dwarf variety of, or closely related to, Navicula gibba, Ehrenb., or some such variable form. These suggestions, however, do not seem likely, since in the cultures under present investigation, where a plentiful supply of water and of mineral salts was always available, no change in the form or size of the diatoms was observable even at the end of three and a half years, but the species remained true to type; and besides this the soil can scarcely be regarded as a medium in which diatoms are subjected to prolonged starvation, especially in a country like England, where there is a fairly adequate rainfall, and where, even in the absence of rain, there is usually a coppious dew. The typical form of Navicula contenta, var. biceps, has also been recorded by Petersen from Danish soils, while specimens of the same variety growing on the leaves of trees at Watten Waven, Dominica, W. Indies, ${ }^{1}$ were found on comparison to show characters identical with those of the soil form. The ability of this diatom to grow in so apparently unpropitious a habitat as the leaves of trees is possibly the result of the extreme moisture of the atmosphere in Dominica, and the diatoms are probably able to obtain all the nourishment they require from this source.

It seems most correct, then, to regard the soil-diatoms as independent species or varieties which by their small size have been enabled to establish themselves in a habitat which would be unable to support life and growth in the larger species.

In the soils examined in this work blüe-green algae are less universally present than are diatoms or green algae, and the species found appear to be more local in occurrence. There can, however, be traced in a number of soils an association between the three species Phormidium tenue, Ph. autumnale, and Plectonema Battersii, at least two of the three species having been found together in no less than sixteen soils, while all three occur in

1 West, W. and G. S. : A Further Contrib. to Freshw. Algae of W. Indies. Journ. Linn. Soc., Bot., xxxiv, I 899 , p. 29 I. 


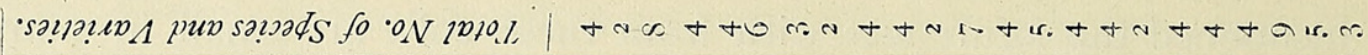

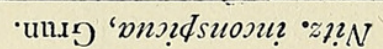

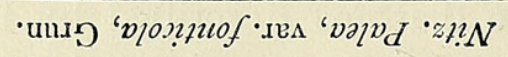

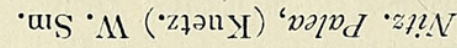

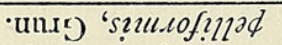

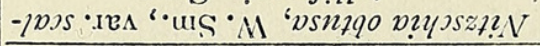

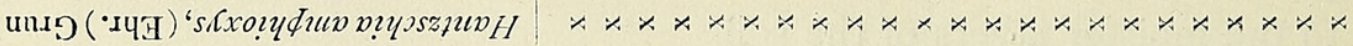

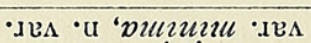

•भuod '

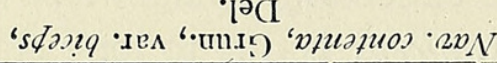

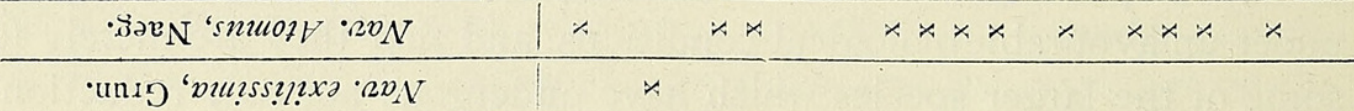

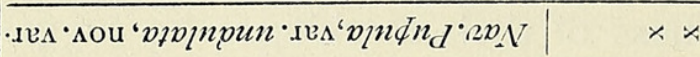

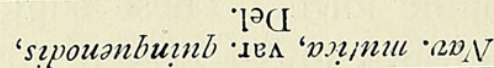

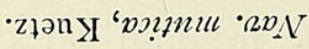

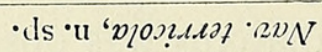

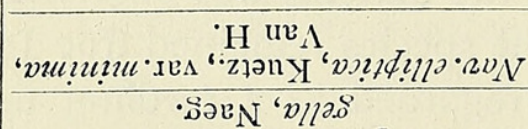

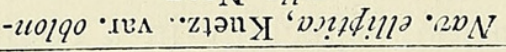

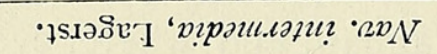

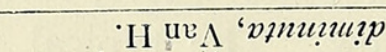

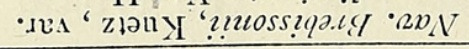
'unis 'menzinoflng $2 x_{N} \quad \star$ •.Ч '

-antinj fo nortopnsout fo a7p(I

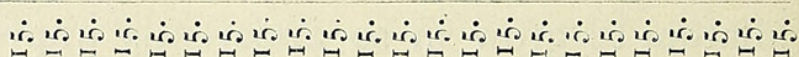

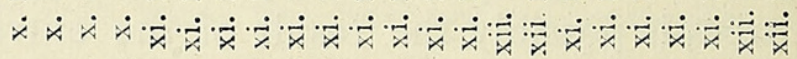

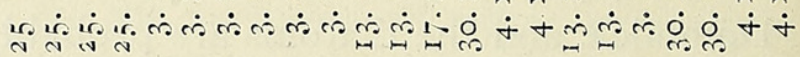

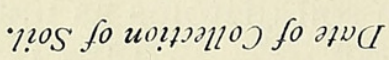

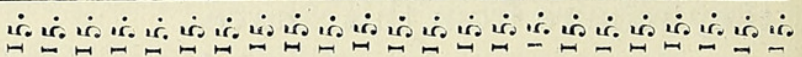
$\dot{x} \dot{x} \dot{x} \dot{x} \dot{x} \dot{x} \dot{x} \dot{x} \dot{x} \dot{x} \dot{x} \dot{x} \dot{x} \dot{x} \dot{x} \dot{x} \dot{x} \dot{x} \dot{x} \dot{x} \dot{x}$

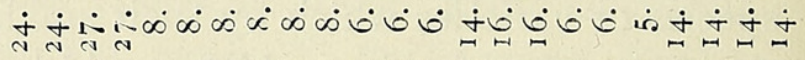

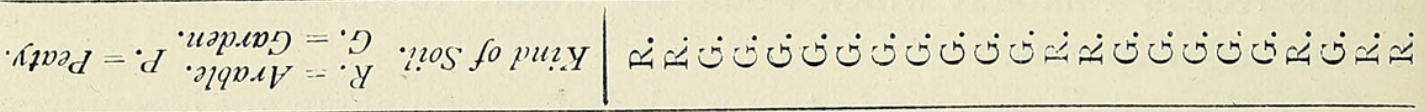

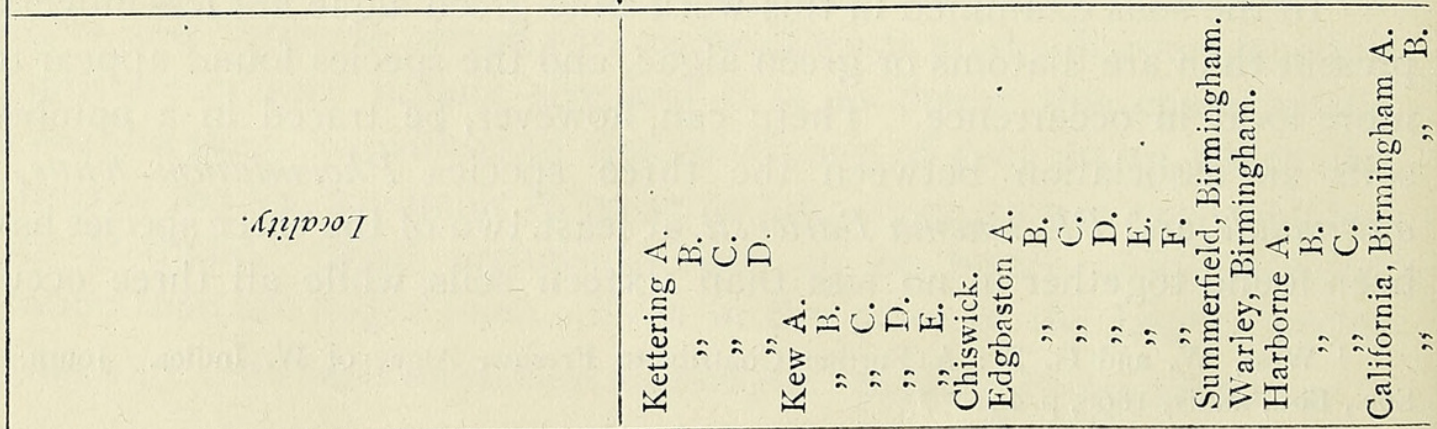




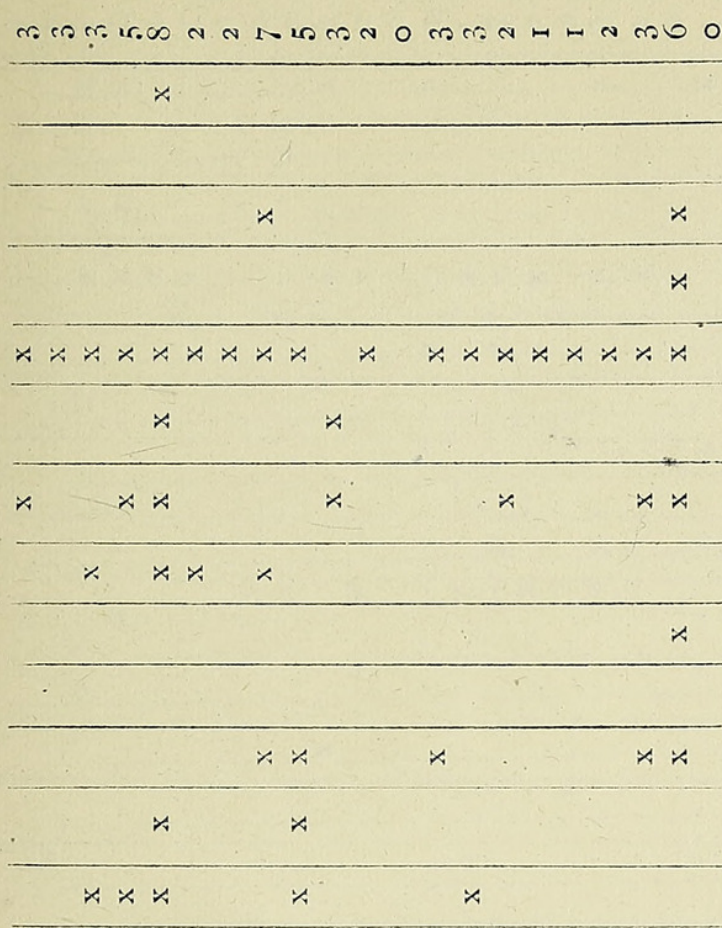

$x$

$\frac{x}{x}$

$x \times x \times x$

$x \times x x \quad x$

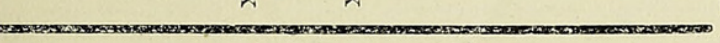

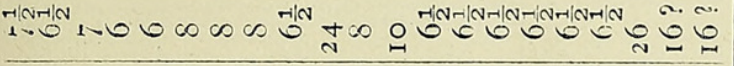
सि

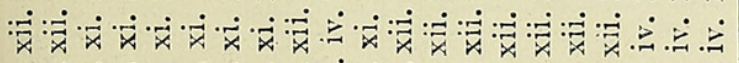

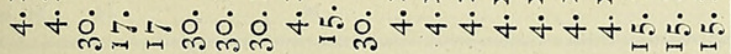

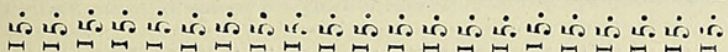
$\dot{x} \dot{x} \dot{x} \dot{x} \dot{x} \dot{x} \dot{x} \dot{x} \dot{x} \dot{x} \dot{x} \dot{x} \dot{x} \dot{x} \dot{x} \dot{x} \dot{x} \dot{x} \dot{x}: \dot{x}: \dot{x}$

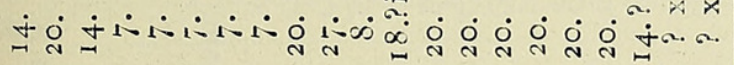
出

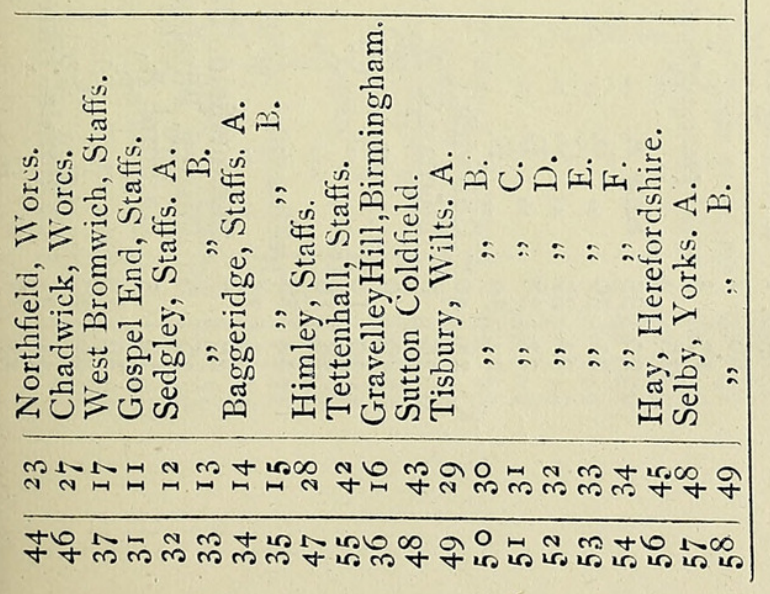




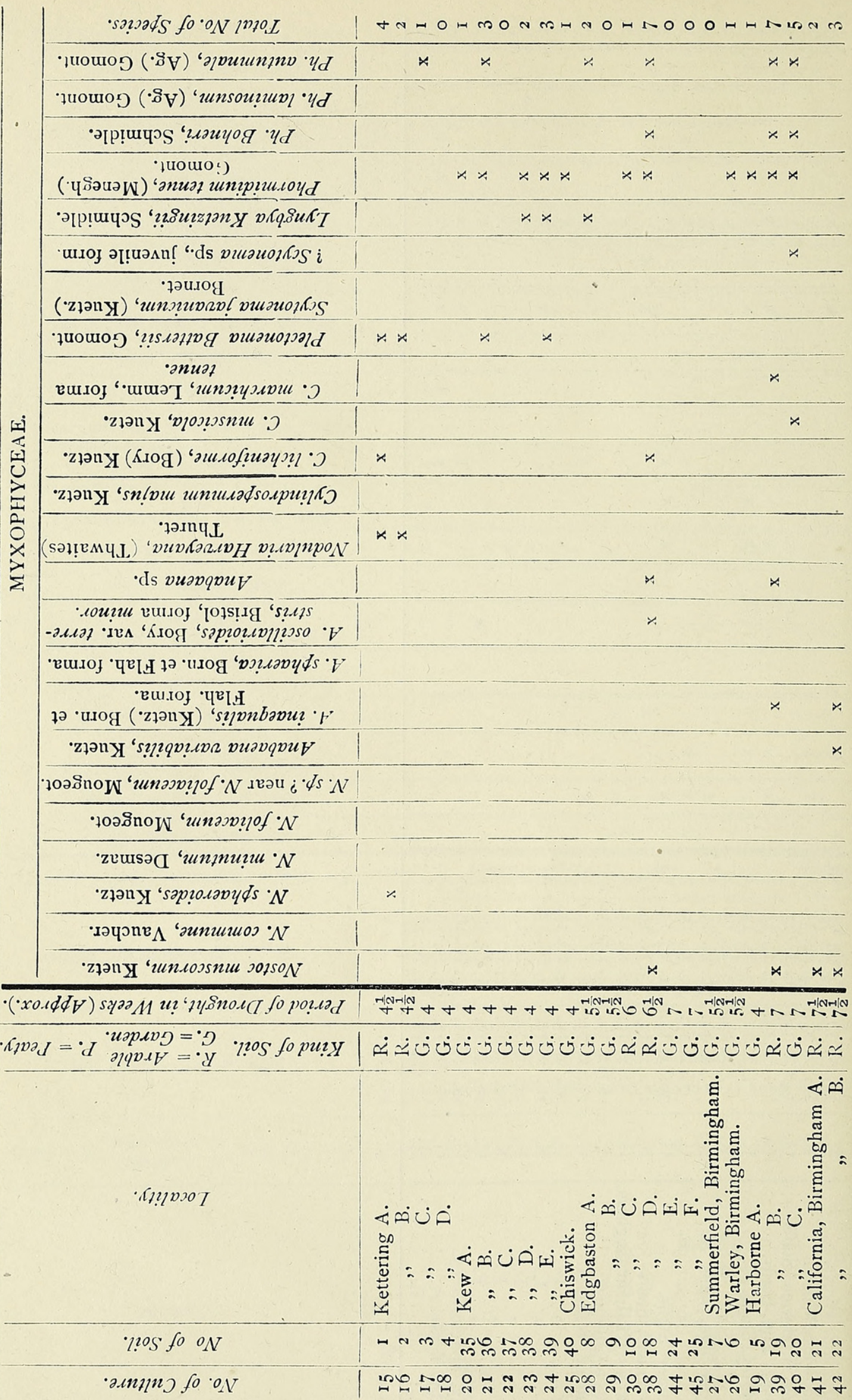


English Soils : an Important Factor in Soil Biology.

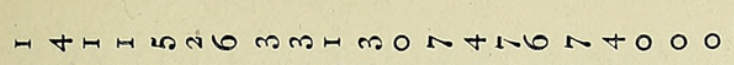

$x \quad x \times x x x$ A $x x x x x x$

is

$\therefore$

$x \quad x \times x \cdot x x x x$

$x \quad x \quad x \quad x$

$x \quad x$

$x x \quad x \quad x x x x x$

$x$

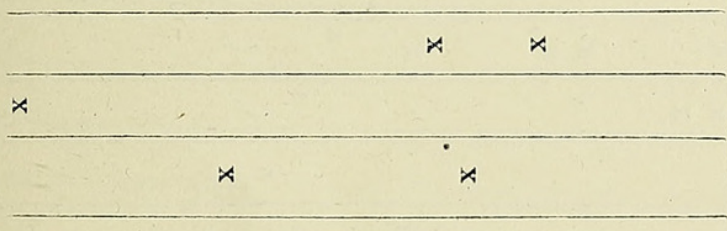

$x$

$x \quad x \times x$

$x \times$

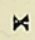

$x$

$x \quad x$

$x$

$x$

$x x x$

$x$

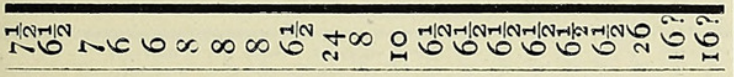

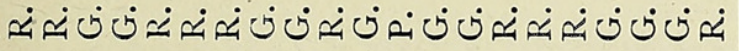

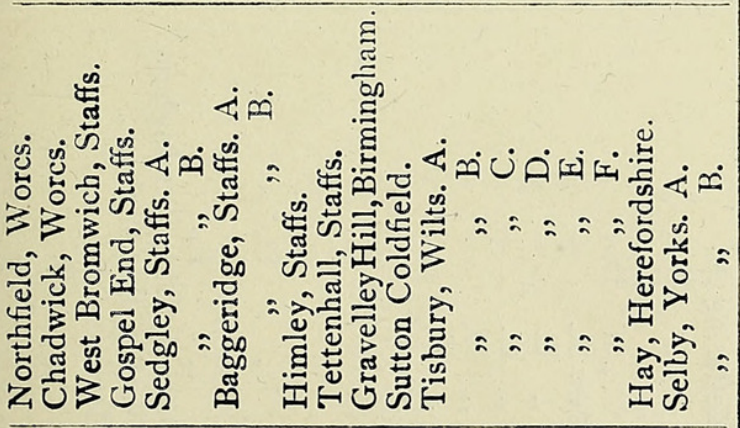

กลส

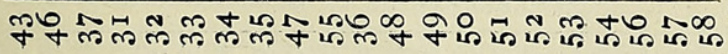




\begin{tabular}{|c|c|c|}
\hline \multirow{3}{*}{ 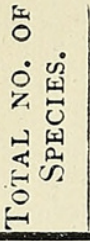 } & $\cdot \operatorname{spas\kappa y\phi ох~} \kappa_{W}$ & 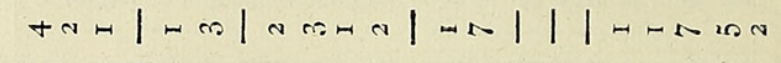 \\
\hline & $\cdot 2 x 2 . .1011 ? .2 x g$ & $t a n t+6 m a t+a n t i n t+a t+t a b 0$ \\
\hline & 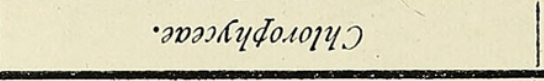 & 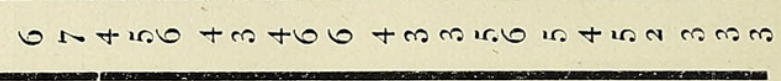 \\
\hline \multirow{20}{*}{ 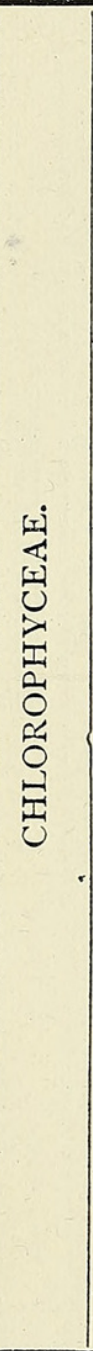 } & 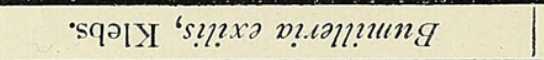 & $x x x x x x \quad x x x \quad x x y x x x x x x x x$ \\
\hline & 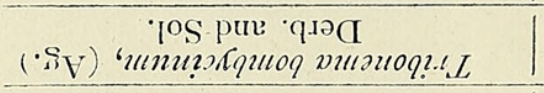 & $x \quad x$ \\
\hline & 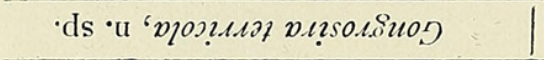 & $x$ \\
\hline & 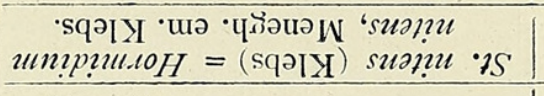 & \\
\hline & 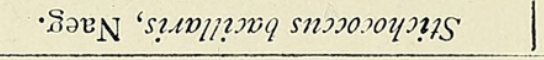 & $x \quad x$ \\
\hline & 'złənу 'pu?ss?muวt' & $x$ \\
\hline & 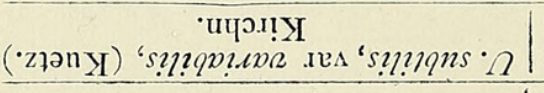 & $x x x \times x x \quad x x \times x x \quad x x x x \quad x$ \\
\hline & 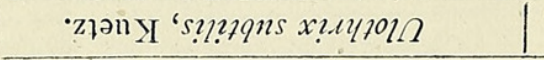 & $x \quad x \times \quad x$ \\
\hline & 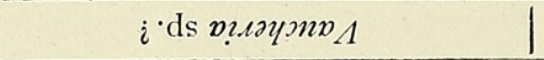 & $x \times$ \\
\hline & 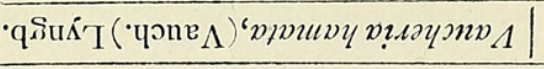 & $x$ \\
\hline & 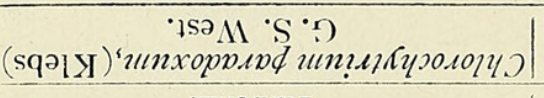 & \\
\hline & 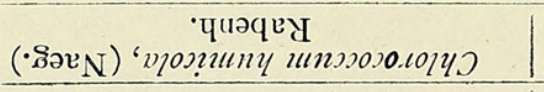 & $x \times x x x x x x x x x x \times x x x x x x x x x$ \\
\hline & 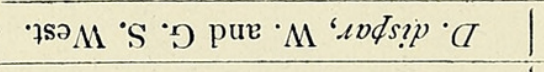 & \\
\hline & 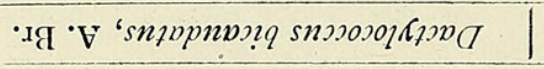 & . \\
\hline & 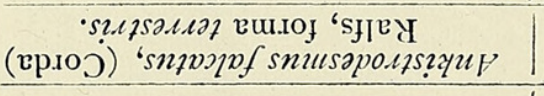 & $x$ \\
\hline & 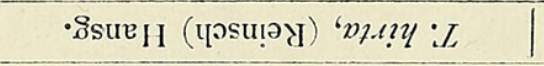 & $x$ \\
\hline & 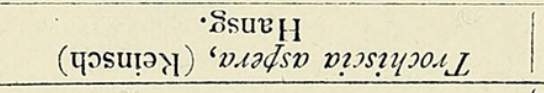 & $x x x x \quad x x x x x \quad x x x x x x \quad x x$ \\
\hline & 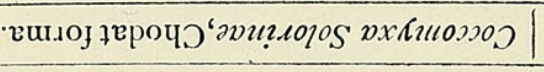 & $x \times$ \\
\hline & 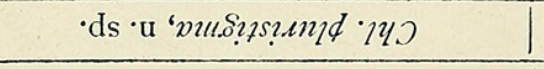 & \\
\hline & 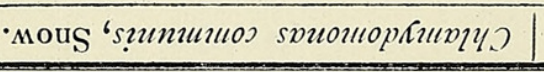 & $x \quad x \quad x$ \\
\hline & murnopoid ssow & $x x x x x x x x x x x x x x x x x x x x x$ \\
\hline$\cdot(\cdot x 0$, & 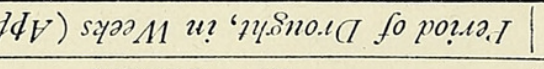 & 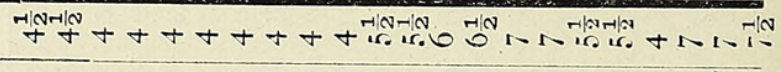 \\
\hline ippad $^{2}$ & 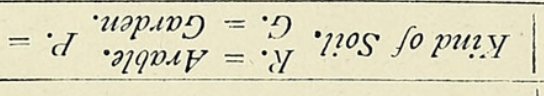 & 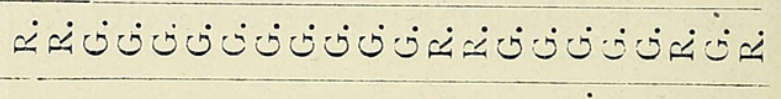 \\
\hline & $\cdot \kappa_{7.7} \times 307$ & 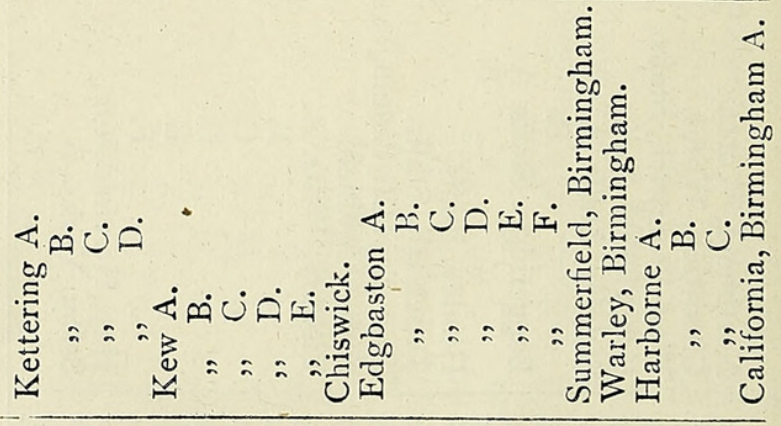 \\
\hline & $2 \operatorname{2os} f 0 \cdot 0 \mathrm{~N}$ & 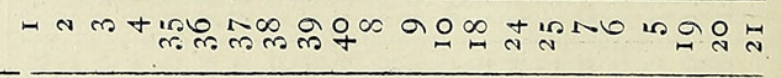 \\
\hline & $\left.\cdot \sin 7 n_{1}\right)$ fo $\cdot 0 \mathrm{~N}$ & 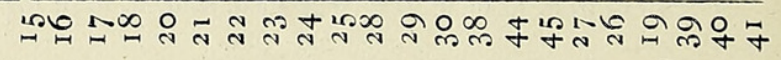 \\
\hline
\end{tabular}




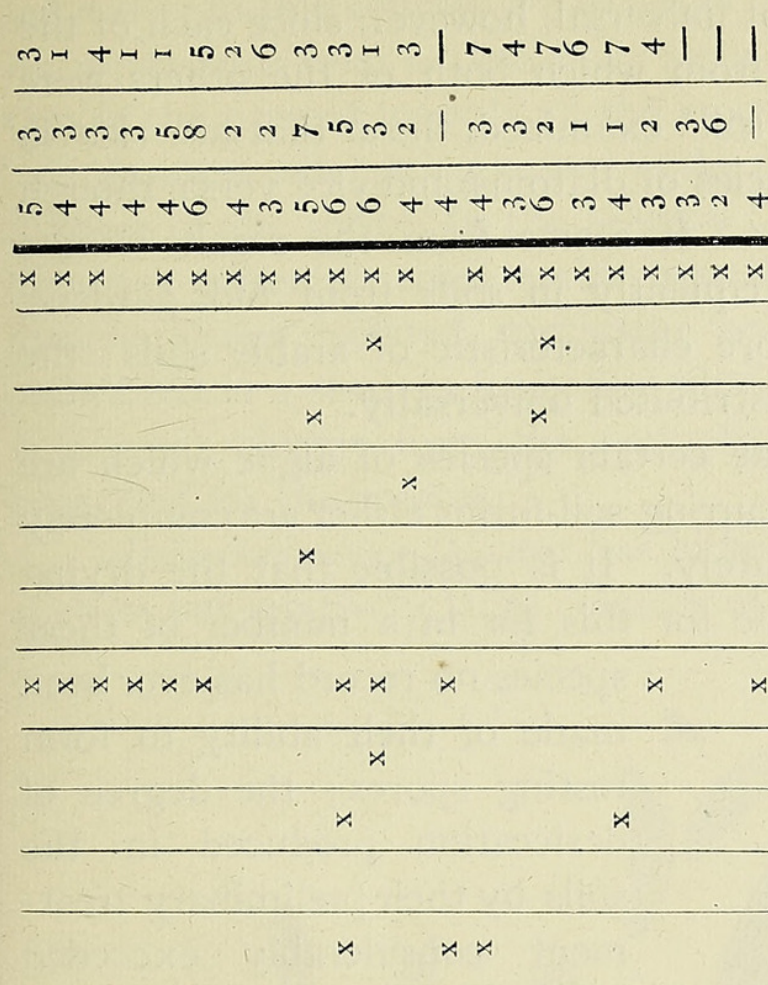

$x \times x \times x \times x \times x \times x \times x \times x \times x \times x x x$

$\frac{\times \sqrt{x}}{\times}$

$x$

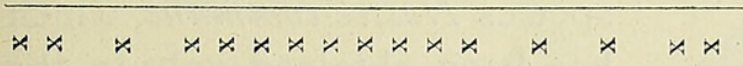

$\frac{x x x x}{x}$

\section{$\star$}

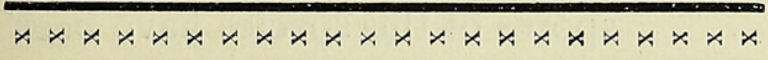

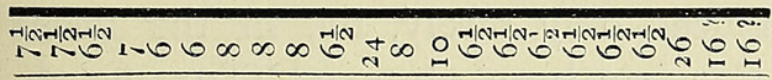
نُ ن

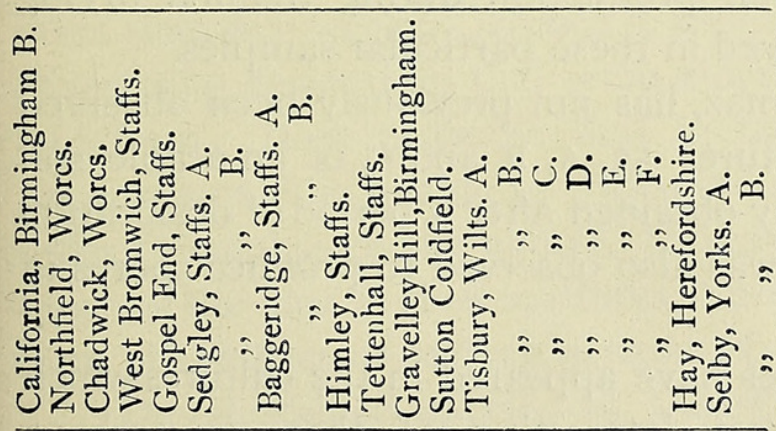

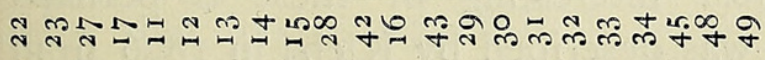

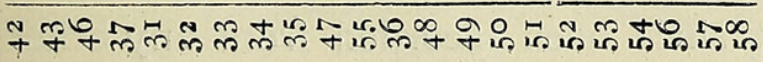


seven of them. This association is not universal, however, since each of the three algae has been found in soils from which both of the others were absent. It is noticeable that, of the soils examined, those that are rich in blue-green algae contain only few species of diatoms, and vice versa, though certain exceptions to this rule occur. It seems from the results of the cultures that diatoms occur most frequently in soils from old gardens, whereas the blue-green algae are more characteristic of arable soils; the green algae, on the other hand, are distributed universally.

It is a feature of the cultures that certain species of algae which are regarded as typical and commonly occurring soil-forms either are completely absent from them or else occur only rarely. It is possible that the drying of the soil-samples may be responsible for this, for in a number of these species no record has ever been
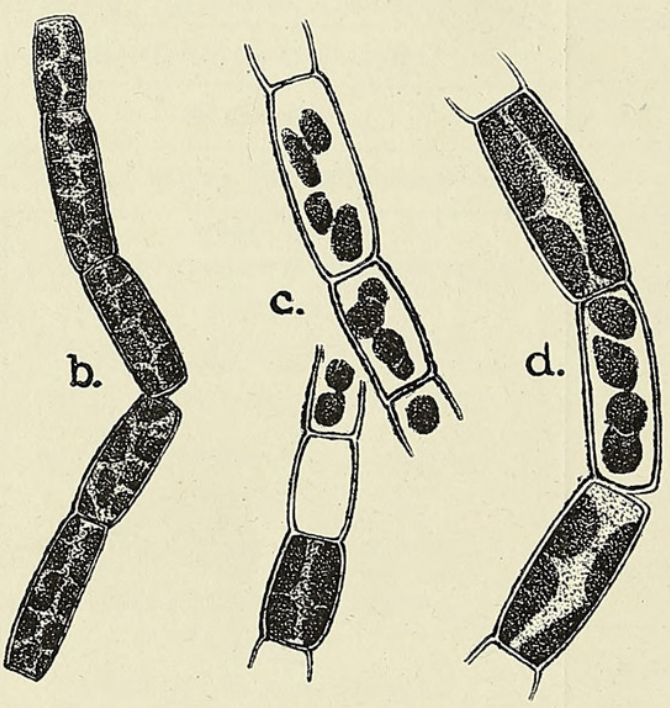

Text-Fig. 1. Bumilleria exilis, Klebs. $a$. and $b$, , vegetative filament's showing variable number of chloroplasts, $\times 825 ; c$. and $d$., filaments showing stages in formation of zoogonidia, $x$ I 435 . unknown, and can therefore be produced only rarely, but in the forms found in these cultures spore-formation has been observed (Text-fig. 4), and it is probably only owing to their production during the first drying of the soils that the species has survived in these particular samples.

Similarly, Nostoc minutum, Desmaz, has not previously been observed to produce resting spores, yet in cultures $53, \mathrm{~A}, \mathrm{~B}$, and C, of an arable soil from Tisbury, the species was not only obtained after a period of desiccation lasting for more than six weeks, but was also observed to produce spores in the culture (Text-fig. 6).

On the other hand, certain species have appeared in the cultures which were entirely unexpected. The most interesting of these is perhaps Bumilleria exilis (Text-fig. 1), which was described by Klebs in 1896 from cultures of a loamy soil, and has not since been recorded from any other 
habitat. In this country no record of the species has ever been made, hence its appearance from no less than forty of the soil-samples under investigation in the present work is all the more remarkable.

Another interesting record is the finding of Chlorochytrium paradoxum in three of the soils. In the Himley (47) and Tisbury, A (49) samples the alga was present in considerable quantity, while in the Sutton Coldfield (48) sample a few isolated specimens only were observed; the cells were embedded in a stratum formed of blue-green algae, but even this association is a great change from the endophytic habit that has previously been described for the species.

Ankistrodesmus falcatus has hitherto been regarded as a purely aquaticspecies, but relatively large colonies of very characteristic form (Text-fig. 2)

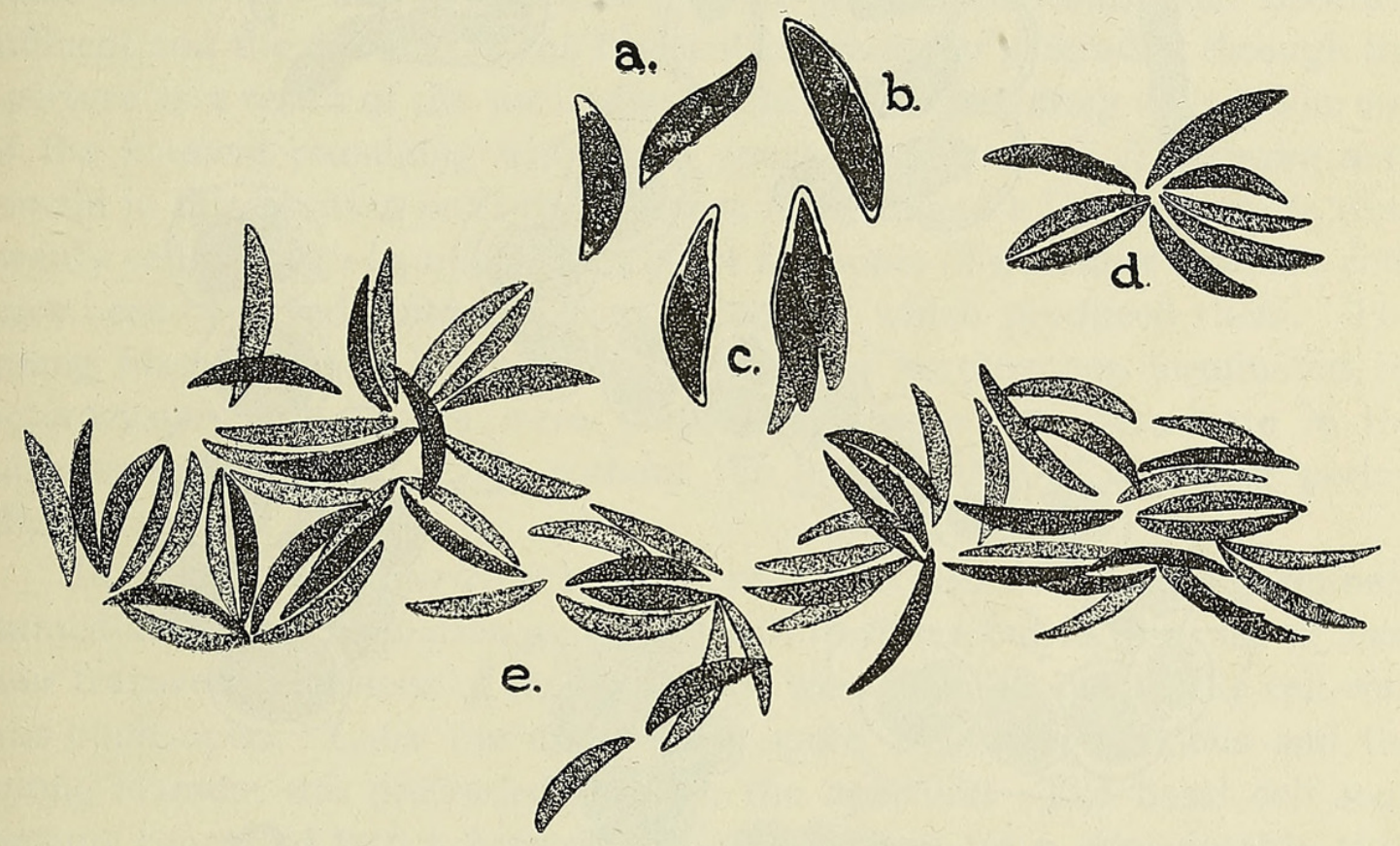

Text-Fig. 2. Ankistrodesmus jalcatus, (Corda) Ralfs, forma terrestris. a., vegetative cells; $b$. and $c$., stages in formation of autospores; $d$., small colony of eight autospores; $e$., large colony showing characteristic arrangement of cells. Figs. $a_{0}-c . \times \mathrm{I}_{4} 435, \mathrm{Figs} . d$. and $e_{.} \times 825$.

appeared in the cultures of the Warley soil, and that after desiccation for more than five weeks. Hence it appears that this species possesses powers of resisting desiccation that seem almost incredible in an alga of such a size and form. It is probable that in the majority of cases Ankistrodesmus falcatus would be unable to withstand desiccation in this manner; hence, in order to emphasize the unusual habitat and extraordinary powers of resistance of the alga in these cultures, it seems advisable to regard it as a special form of the species under the name $A$. falcatus, forma terrestris.

The described species of Gongrosira also are aquatic in habit; the form that has appeared from three widely separated soil-samples, while obviously belonging to this genus, differs from those already described in 
several important particulars and is evidently a new species probably growing only in soils.

Among the blue-green algae, the occurrence of Plectonema Battersii in

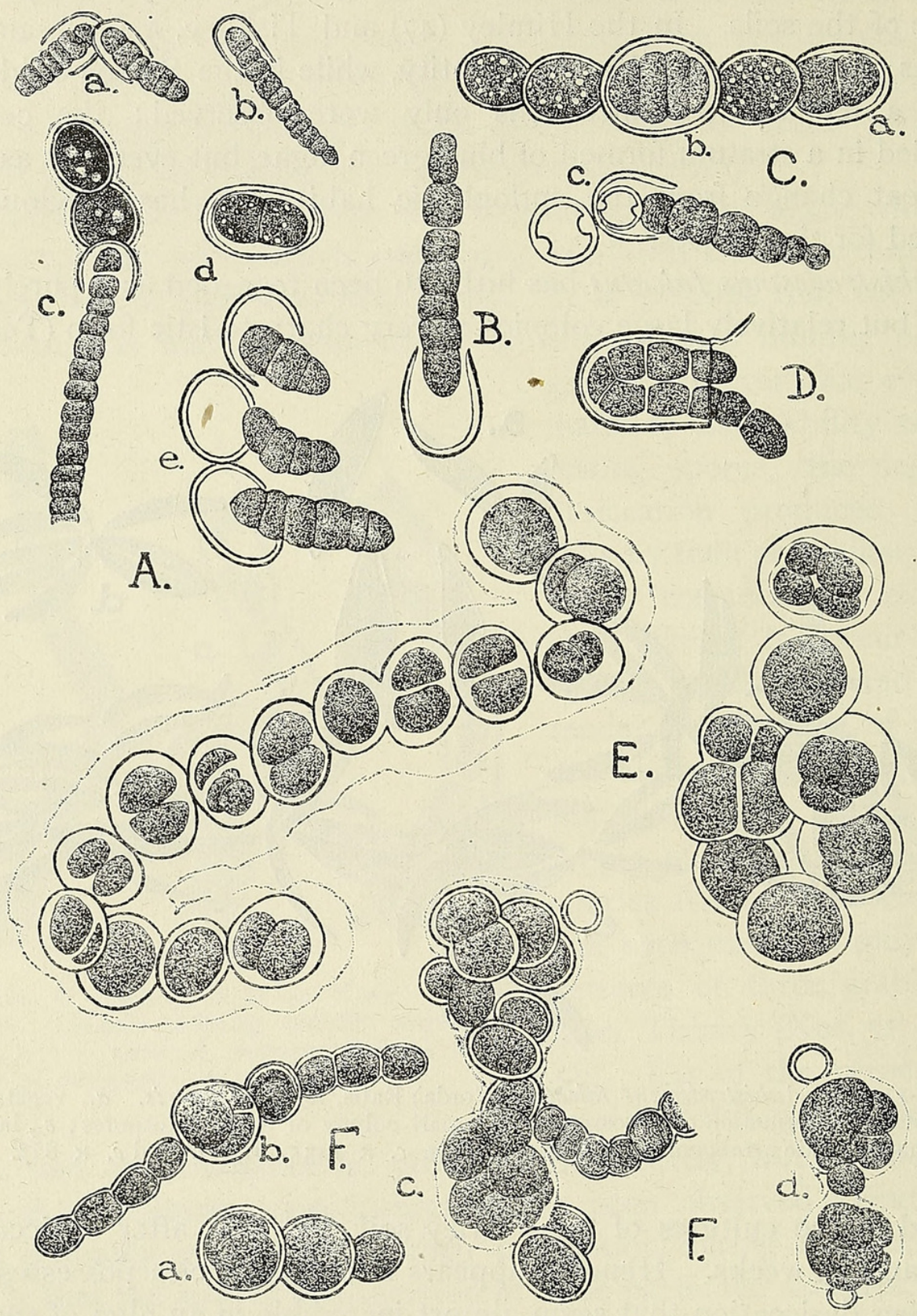

Text-fig. 3. Germination of spores of some Myxophyceae. A. Nodularia Harveyana, (Thwaites) Thuret; a.-c. from old stored soil, $1846 ; d_{0}$. and $e$. from recent soil. B. Anabaena oscillarioides, Bory, forma. c. Anabaena sphaerica, Born. et Flah.; a.-c., successive stages in germination. D. Cylindrospermum licheniforme, (Bory) Kuetz. E. Nostoc sphaeroides, Kuetz. F. Nostoc muscorum, Kuetz.; $a_{0}-d$., successive stages in germination. All figs. $\times 825$.

thirteen of the soil-samples is interesting, since it has previously been described only as a marine aquatic species.

Owing to the conditions under which the experiments have been carried out, a number of observations have been made of new or interesting 
stages in the development and life-history of a number of the species found. This is especially true of the germination and development of some of the blue-green algae, which in some cases have seemed somewhat obscure. In these cultures two quite different methods of germination were observed, a direct germination into a more or less typical vegetative plant and germination into what can only be regarded as a juvenile form bearing none of the characters of the adult plant. The former appears to be by far the more general method of germination and may be subject to slight variation in details (Text-fig. 3, A-D); the latter is largely found in the genus Nostoc (Text-fig. 3, E and F).

In Nodularia Harveyana (A) and in Anabaena oscillarioides forma (B) a single transverse division of the protoplast of the spore appears to take place before the wall is ruptured; some part of the wall then becomes diffluent and the free end of the filament is gradually protruded through the aperture as a result of the succeeding divisions of the young cells. The end of the filament remaining within the spore in Nodularia Harveyana may remain in this position until the filament has attained a length of more than twenty cells, though in other cases short filaments of not more than six cells have been observed quite free from the spores which produced them. The young filaments soon become broken up into hormogones terminated by heterocysts. The spores were frequently observed to germinate in the cultures while still in series, without the interposition of a resting period after formation.

In Anabaena sphaerica (C) the spores were also observed to germinate immediately after formation and while still in series, but in this case at least four transverse divisions of the protoplast were effected before the cell-wall was burst open. Later the end of the spore became gelatinous and the young filament was protruded through the aperture. The basal cell soon became converted into a heterocyst and remained for a considerable time within the old spore-cavity, while the free end extended farther and farther from the spore as a result of succeeding divisions of the young cells.

In Cylindrospermum licheniforme (D) the end of the spore was observed to open as a lid to permit the extrusion of the young filament. Several divisions of the protoplast took place before the wall was ruptured, and it sometimes, though not always, happened that a doubling of the filament took place so that both ends of it were protruded at once through the terminal aperture, as shown in the figure.

In Nostoc commune (Text-fig. 4 ) a rejuvenescence of the protoplasm appeared to take place inside the spore, with the result that the spore-wall burst and the contents were extruded either immediately or after a single division within a mucilaginous envelope formed from the inner layers of the spore-wall. In most cases this aperture was produced by a dissolution of part of the wall, but in a few cases a circular portion of the wall was 
observed to open as a lid. Within the mucilaginous investment a few divisions were observed to take place, resulting in the formation of a short irregular filament usually terminated at each end by a heterocyst. Heterocysts arranged in short series of two or three were often observed at a slightly later stage of development. It is probable that the cells of the

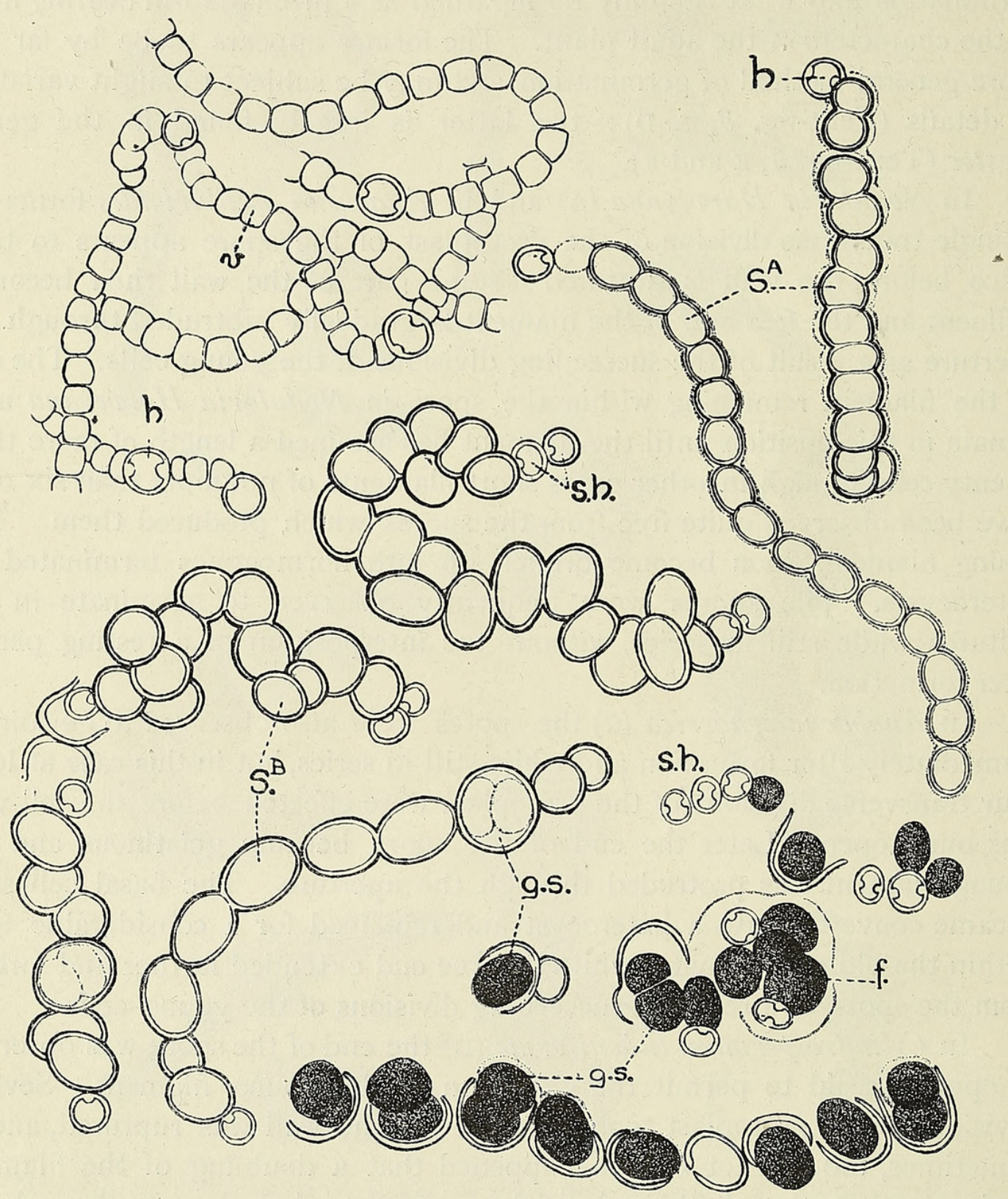

TEXT-FIg. 4. Nostoc commune, Vaucher, from arable soil, Tisbury, Wilts. $h_{\text {. }}$, heterocyst; s.h., seriate heterocysts; $\mathrm{S}^{\mathrm{A}}$, spores of form $\mathrm{A} ; \mathrm{SB}^{\mathrm{B}}$, spores of form B; g.s., germinating spore of form $\mathrm{B} ; f$., young filament from germinated spore; $v$., vegetative cells of form A. All figs. $\times 825$.

young filaments divide irregularly after a time, since numbers of small colonies were observed in the cultures comparable to the juvenile forms described below.

In other species of Nostoc direct germination into a short filament, as observed in $N$.commune, did not usually take place, and juvenile forms were 
frequently found. The spores germinated in the cultures either after a period of rest or almost immediately after formation. The contents of the spore were observed to become much increased in volume (Text-fig. $3, \mathrm{~F}$, $a$ and $b$ ) and the entire spore-wall to be gradually converted into mucilage. Within this mucilaginous investment the protoplast began to divide in all directions of space, producing a more or less spherical cluster of cells in which no trace of a filamentous arrangement could be detected. These cells continued to divide until a large irregular mass of closely clustered cells was produced which bore no specific characters at all. Heterocysts were usually

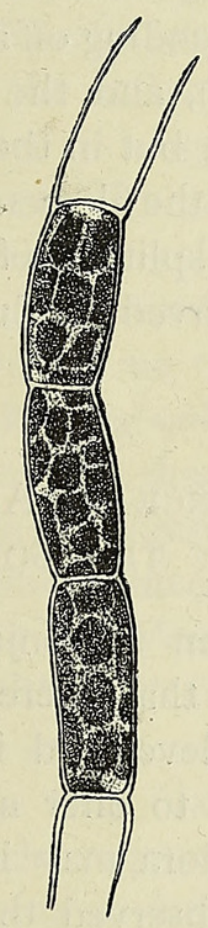

a.
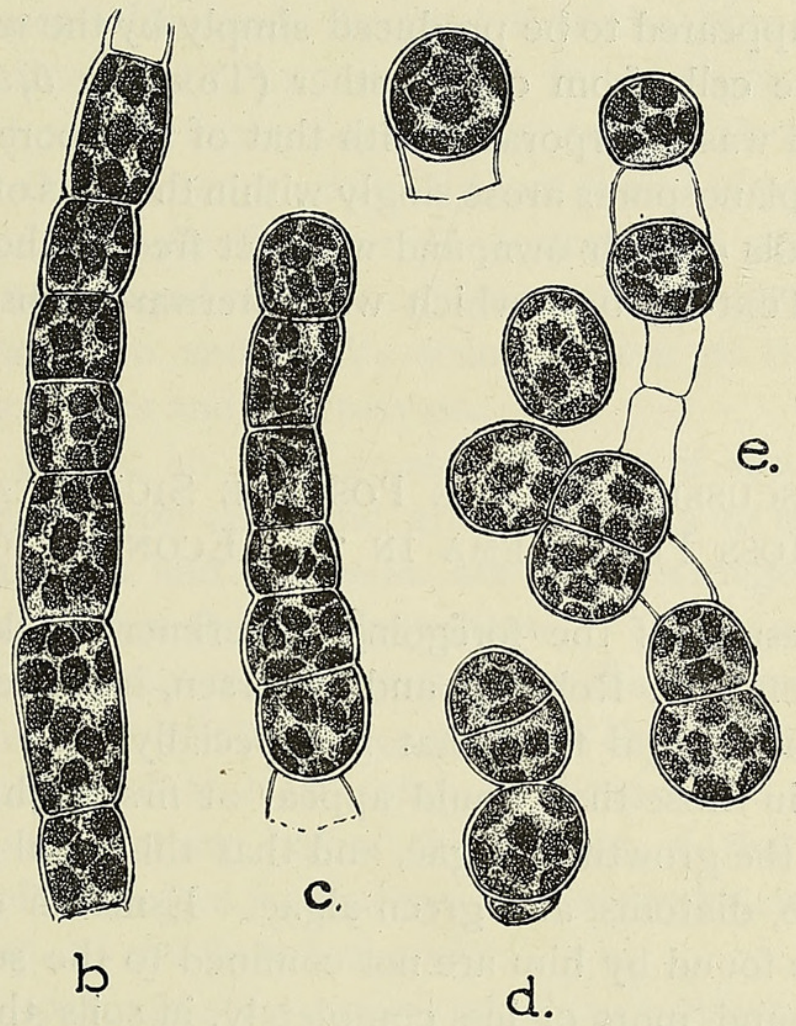

TeXT-Fig. 5. Tribonema bombycinum, (Ag.) Derb. and Sol. a., typical vegetative filament with walls of end cells broken into $\mathrm{H}$-pieces; $b$. and $c_{\text {. }}$, somewhat irregular filaments probably produced as a result of cultural conditions ; $d$., breaking up of filament into aplanospores ; $e$., formation of aplanospores within cells of filament and liberation by splitting of mother-cell wall. $\quad \times \quad 825$.

completely absent except in quite young colonies, where a single heterocyst was often observed at the surface of the cell-cluster (Text-fig. 3, F, d). The mucilaginous investment usually became firm on the outside and of a light brown colour, and remained permanent. In some cases in the cultures the alga remained in this condition for a considerable time, and sometimes the conditions were such that the cells at this stage became converted directly into resting spores without having developed into the adult stage at all, but this was probably quite abnormal and due entirely to the cultural conditions. In the majority of cases, sooner or later the juvenile form became gradually transformed into the adult stage with definite 
filaments producing heterocysts and spores in the normal manner, and in this stage it was possible to identify the species more or less accurately. In Text-fig. 4, E and F, are depicted the initial stages of this mode of germination in two species, Nostoc sphaeroides, Kuetz., and N. muscorum, Kuetz.

Among the Chlorophyceae the most interesting record of this kind is the formation by Tribonema bombycinum of a somewhat unusual type of aplanospore. The filaments of this species appear to be somewhat sensitive to cultural conditions, as can be seen in Text-fig. $5, b$ and $c$, and in the cultures of one soil were observed to be converted into one- or two-celled fragments which rounded themselves off from the rest. In some cases these fragments appeared to be produced simply by the rounding off and breaking away of the cells from one another (Text-fig. 5,d), and the wall of the original cell was incorporated with that of the spore; but in the majority of cases the aplanospores arose singly within the cells of the filament, producing new cell-walls of their own, and were set free by the splitting of the mothercell wall (Text-fig. 5,e) which was afterwards observed gradually to disintegrate.

\section{Discussion of the Possible Significance of Algae and Moss Protonema in the Economy of the Soll.}

The results of the foregoing experiments, taken in conjunction with those of Esmarch, Robbins, and Petersen, indicate that there is in many soils a definite algal flora that is especially well developed in cultivated soils, even in those that would appear at first sight to offer no conditions suitable to the growth of algae, and that this algal flora may include bluegreen algae, diatoms, and green algae. Esmarch observed that the bluegreen algae found by him are not confined to the surface-layers of soil, but are to be found, more or less completely, in soils that have been cultivated, even to a depth of $10-25 \mathrm{~cm}$., while a smaller number of species may be found as much as $40-50 \mathrm{~cm}$. below the surface; and he observed that the species in the lower layers are almost identical with those of the surfacelayers of the soil. He attributes this extensive distribution of blue-green algae in cultivated soils chiefly to the cultivation of the ground, in that by ploughing, digging, and hoeing not only are the conditions of the soil made more favourable to the growth of algae, but also fresh layers of soil are constantly being brought to the surface, and the surface-algae buried more and more deeply. He considers that the spores contained in the new surfacelayers germinate on being exposed to the light and form fresh vegetative filaments on the surface, which at a later date are again buried. As other factors working for the distribution of algae in the soil he considers that the percolation of water and the burrowing of worms and other small animals are also effective. 
The physiological experiments of Boresch, ${ }^{1}$ Schindler, $^{2}$ and ${ }^{3}$ and Magnus, ${ }^{2}$ showing that certain algae are able to build up chlorophyll and phycocyanin and to grow in the dark, provided that sufficient nitrogenous food material is available, appear to have an important bearing on the mode of life of soil-algae, and suggest that it is quite possible for algae not merely to exist passively in the lower layers of the soil, but also to carry on active growth, for some time at any rate. In order to test this possibility Esmarch carried out a series of experiments upon algae specially buried in the soil at a known date and available for microscopic examination at any time; the cultures of the algae were kept in the dark.

From these experiments Esmarch observed that the blue-green algae enclosed in the soil retained their normal colour for some time, but that after a shorter or longer period, depending on the composition of the soil and the species of alga, the filaments gradually lost their blue-green colour and finally became yellowish. At first the dimensions and appearance of the filaments remained unchanged and the cells appeared perfectly healthy, but after some time distortion and finally disintegration of the filaments took place, leaving only spores and heterocysts.

He observed that Nostoc sp. had greater powers of resistance than Anabaena and Cylindrospermum spp., and attributed this to the fact that the mucilaginous investments and cell-walls are much stronger and more permanent in the Nostoc species than in the others.

Esmarch's work is thus extremely important in that it shows that not only is there an extensive flora of blue-green algae in the top layers of the soil, but also that filaments of at least some of these algae are able to continue their vegetative functions below the surface of the ground for periods varying in individual cases from three to six weeks, or even, as in the case of one Nostoc sp., as much as ten weeks.

Estimations of the approximate numbers of algae present in different soils in relation to other organisms have not yet been attempted, but the large number of different species found in English soils rather suggests that the proportions would be high for this country. No recent sample of a cultivated soil has been investigated which yielded fewer than four different species, and only four samples yielded fewer than seven species; many of the cultures were found to contain at least a dozen, while several yielded as many as seventeen or eighteen different species and varieties, in addition to the moss protonema which was obtained from every soil. It is inconceivable that such an extensive population of chlorophyll-containing organisms can be without its effect both on the other organisms in the soil

1 Boresch : Die Färbung von Cyanophyceen und Chlorophyceen in ihrer Abhängigkeit vom Stickstoffgehalt des Substrats. Jahrb. für Bot., lii, 19 I 3 ; pp. I $45^{-8} 5$.

2 Magnus, W., and Schindler, B. : Ueber den Einfluss der Nährsalze auf die Färbung der Oscillarien. Ber. der Deutsch. Bot. Ges., xxx, I9 I 2-13, p. 3I4.

${ }^{3}$ Schindler, B. : Ueber den Farbenwechsel der Oscillarien. Zeitsch. f. Bot., v, r9I 3, pp. 553-5. 
and on the soil itself, but up to the present too little is known on the subject to make any very definite statements in this direction.

It was thought by Frank $^{1}$ and by Schloesing and Laurent ${ }^{2}$ that algae in the soil had the power of fixing atmospheric nitrogen, but later experiments by Kossowitsch ${ }^{3}$ showed conclusively that algae by themselves are quite unable to carry on these activities. Kossowitsch suggested, on the contrary, that nitrogen fixation was the result of bacterial activity, and definitely proved this to be true in a few of his cultures. He observed, however, that the presence of certain algae in the soil is highly advantageous to nitrogen fixation, and concluded that there exists a symbiotic relationship between the algae and bacteria of the soil as a result of which nitrogen compounds are added to the soil. From the observation of Berthelot ${ }^{4}$ that an increase in the nitrogen content of the soil does not continue unless fresh organic material is added to the soil, and that of Gautier and Drouin ${ }^{5}$ that organic compounds destitute of nitrogen serve to stimulate nitrogen fixation in the soil, together with his own observation that the addition of sugar to certain cultures containing algae and bacteria made little difference to the amount of nitrogen fixed by the organisms, though in the absence of algae the difference was very considerable, Kossowitsch concluded that the bacteria were able to use certain organic compounds supplied by the algae. He suggested that the mucous sheaths always observed to be present round those algae having the greatest effect on nitrogen fixation probably provide the carbohydrate needed by the bacteria for growth; in return the algae are supplied with the nitrogenous substances without which they are unable to develop.

Further experiments by Bouilhac and Giustiniani ${ }^{6}$ showed that in sand completely destitute of organic matter and of nitrogen compounds a mixture of soil-bacteria and algae are not only able to develop normally, but also to enrich the soil with nitrogen sufficiently to support the growth of

1 Frank, B. : (a) Ueber den experimentellen Nachweis der Assimilation freien Stickstoffs durch erdbodenbewohnende Algen. Ber. der D. Bot. Ges., vii, I 889, pp. 34-42.

(b) Ueber den gegenwärtigen Stand unserer Kenntnisse der Assimilation elementaren Stickstoffs durch die Pflanze. Ber. der D. Bot. Ges., vii, I889, pp. 234-47.

(c) Frank, B., and Otto, R. : Untersuchungen uiber Stickstoff-Assimilation in der Pflanze. Ber. der D. Bot. Ges., viii, I 890 , pp. 331-42.

2 Schloesing, fils, and Laurent, E. : Recherches sur la fixation de l'azote libre par les plantes.

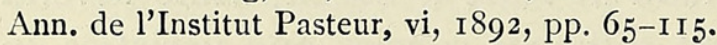

3 Kossowitsch, P.: Untersuchungen über die Frage, ob die Algen freien Stickstoff fixiren. Bot. Zeit., I894, Heft 5, pp. 98-1 г6.

4 Berthelot, M. : Recherches nouvelles sur les microorganismes fixateurs de l'azote. Compt. Rend., cxvi, I 893, pp. 842-9.

5 Gautier and Drouin : Recherches sur la fixation de l'azote par le sol et les végétaux. Compt. Rend., cvi, I888, pp. 754, 863, 944, I098, I I 74, I 232, I605.

6 (a) Bouilhac, R. : Sur la fixation de l'azote atmosphérique par l'association des algues et des bactéries. Compt. Rend., cxxiii, 1896, pp. 828-30.

(b) Bouilhac, R., and Giustiniani : Sur une culture de sarrasin en présence d'un mélange d'algues et de bactéries. Compt. Rend., cxxxvii, I903, pp. I274-6. 
higher plants; while still more recently Pringsheim ${ }^{1}$ has shown that the ability of bacteria to fix nitrogen is closely dependent upon the presence of blue-green algae.

Esmarch ${ }^{2}$ and Robbins ${ }^{3}$ both incline to the belief that in certain soils at any rate the presence of algae, especially of blue-green algae, is an important factor in the fixation of nitrogen by bacteria. In certain of the Colorado soils large quantities of nitrate are built up through the agency of Azotobacter chroococcum despite the fact that these soils are poor in organic matter, and Robbins considers that the bacteria probably derive their organic material from the mucilaginous investments of the blue-green algae, which he shows to be present in considerable numbers.

Recently Nakano ${ }^{4}$ investigated the relationship existing between algae and Azotobacter and shows that it holds not only for blue-green algae but also for certain green algae. He points out that the pure cultures of Azotobacter fix less nitrogen than similar cultures to which pure algae have been added, and also shows that these green algae are able to build up chlorophyll in the dark not only on organic culture-media but also in aqueous culture-solutions of mineral salts into which sugar has been introduced. Nakano did not deal specifically with soil-forms, but both of these observations have a good deal of significance in considering the possible economic functions of soil-algae.

According to Russell ${ }^{5}$ the activities of Azotobacter are limited to wellaerated soils that are sufficiently provided with calcium carbonate, potassium salts and phosphates, carbonaceous material of the right kind, and moisture, and do not take place except at a comparatively high temperature. $\mathrm{He}$ admits, however, that is impossible to argue from a culture-solution to a soil, and Robbins's statement that Azotobacter chroococcum. is the chief nitrogen-fixing bacterium in Colorado soils that are poor in organic material rather suggests that Azotobacter may work more efficiently in conjunction with blue-green algae than with the sugar and other carbohydrates used in the cultures of Koch, Pringsheim, and other investigators.

In their researches on the fixation of nitrogen by the soil Gautier and Drouin ${ }^{6}$ observed that in unsown soils which contain only ammonia as their source of nitrogen and are destitute of organic matter, there is a constant decrease in the amount of ammonia present which is due partly to its slow conversion into organic substances in the soil and partly to its escape into the air. But if algae are present the amount of nitrogenous organic

1 Pringsheim, E. : Kulturversuche mit chlorophyllführenden Mikroorganismen. III : Zur Physiologie der Schizophyceen. Cohns Beiträge z. Biol. d. Pflanzen, Bd. xii, pp. 99-Io7.

2 Esmarch : loc. cit., I9I4.

\& Loc. cit.

4 Nakano, H.: Untersuchungen über die Entwicklungs- und Ernährungsphysiologie einiger Chlorophyceen. Journ. of Coll. of Science, Imperial Univ., Tokyo, vol. xl, i 91 7, Art. 2, p. 66 \&c.

5 Russell, E. J. : Soil Conditions and Plant Growth. Monographs in Biochem., 19I 5, p. 97.

6 Gautier and Drouin : loc. cit., pp. I I 74-6, I $232-4$. 
substance built up is greatly increased, while the loss of ammonia into the air is reduced to a minimum ; similar results were also obtained with soils in which higher plants were growing. Hence Gautier and Drouin regarded soil-algae less as factors in the acquisition of nitrogen by the soil than as agents for the transformation of the ammoniacal substances already present into more complex organic substances, and thus as factors in helping to bring about the nitrogen cycle of the soil.

This consideration of the facts already ascertained indicates very clearly that the part that living algae play in the economy of the soil is no inconsiderable one, though the difficulties in the way of establishing direct evidence are very great, and much work will be necessary before any very definite statements can be made. It is, on the other hand, quite certain that by their death algae contribute very largely to the fertility of soils in that they present considerable quantities of organic material to the putrefactive bacteria for decomposition.

The extraordinary property which moss protonema and many of these soil-algae possess, of being able to retain their vitality for very long periods, even under conditions of complete drought, has already been described elsewhere ${ }^{1}$ and it is to be emphasized in this connexion that all of the forms which exhibit these powers build up considerable quantities of a fatty oil in their cytoplasm, so that the chemical energy stored up in them is very high, and their value as sources of energy for other organisms correspondingly great. In the cultures under observation certain protozoa have been observed to feed quite extensively on soil-algae, specimens being frequently found containing a dozen or more inclusions that might be either diatoms or green algae, or more rarely blue-green algae. Whether this condition exists in nature or is merely an accident due to the presence of a greater amount of water than is usually available under natural conditions in the soil it is impossible to say, but it is probable that algae may also contribute largely to the nutrition of some of the lower organisms of the soil, and especially of worms.

Again, if algae are present in any quantity in a soil, their physiological functions of respiration and photosynthesis must have a certain effect upon the nature of the gases in the soil, while their mucous investments probably play an important part, especially in sandy soils, in helping the soil to retain its moisture.

1 Bristol, B. M.: ( $a$ ) On the Remarkable Retention of Vitality of Moss Protonema. New Phyt., vol. xv, No. 7, July, 1916, p. I37.

(b) On the Retention of Vitality by Algae from Old Stored Soils. New Phyt., vol. xviii, Nos. 3 and 4 , 1919 . 
V. Descriptive Notes on the Species found.

Myxophyceae.

I. Phormidium tenue, (Menegh.) Gomont.

This species, found in twenty different samples of soil, is the commonest blue-green alga in the soils examined. As observed in the cultures, it agreed exactly in dimensions and all other characters with the typical form from which the species was described.

2. Phormidium Bohneri, Schmidle.

Up to the present time this species has been described only from damp soil in Africa, but there is no doubt that a Phormidium found growing from four of these soil-samples must belong to this species. The algal filaments were almost straight, but slightly curved and interwoven to form a thin pale blue-green stratum. The cells were usually a little shorter than broad, but might be of equal dimensions or rather longer than broad; no constrictions were observed between the cells, and the end cell was generally rounded, though occasionally it was somewhat swollen and formed a knoblike termination to the filament. The sheath was colourless and rather thin, and the breadth of the filament about $2 \mu$.

3. Phormidium laminosum, (Ag.) Gomont.

The alga identified under this name occurred in one soil only, but the extraordinarily varied habitat already described for this species makes the record an extremely interesting one; there are few species of algae capable of living in places so widely different as hot springs, standing water, rocks moistened by spray from a waterfall, and garden-soil. The form observed in the cultures agreed almost exactly with the typical form, but the filaments were slightly wider, being $2 \mu$ in breadth instead of only $\mathrm{I} \cdot 5 \mu$.

4. Phormidium autumnale, (Ag.) Gomont.

Next to $P$. temue, this species occurred most frequently in the soils examined, having been found in the cultures of nineteen samples. The filaments were interwoven to form expanded strata of a deep brownish-green or almost black colour on the surface of the soil and on the sides of the culture-vessel. The ends of the filaments were slightly tapering; the end cell was sometimes capitate and sometimes rounded, and in this case the last two or three cells of the filament might be slightly curved. The breadth of the filaments was $4-8 \mu$.

5. Lyngbya Kuetzingii, Schmidle.

A blue-green alga very closely resembling this species was found in the cultures of seven of the soils, with usually straight but occasionally curved filaments matted together to form a dark brownish-green expanded stratum. The filaments were 3 to $3 \cdot 5 \mu$ broad, bounded by a strong colourless sheath; and the end cells were rounded without being tapering. Very 
occasionally a slight constriction between the cells could be observed, but this was not general. This species has previously been recorded only from running water, where it grows attached to water-plants, hence its appearance from the soil-samples is surprising.

6. Nostoc muscorum, Kuetz.

This species was obtained from five soils, but, possibly owing to cultural conditions, it differed slightly from the typical form. Young colonies were globular, with closely matted filaments coiled in loops towards the periphery of the colony, where the sheaths of the individual filaments could be distinguished. The whole was surrounded by a firm mucous sheath that gradually became light brown in colour. The colonies retained this form until they were 100 to $200 \mu$ in diameter, but sooner or later they split to form an expanded leaf-like stratum in which the characters of the filaments could be distinguished. The cells were spherical or shortly barrelshaped, 3 to $5 \mu$ broad; the heterocysts almost spherical and 5 to $7 \mu$ broad; the spores 6 to $8 \mu$ long by 8 to $9.5 \mu$ broad, arranged in long chains and possessing smooth yellowish walls.

7. Nostoc foliaceum, Mougeot.

A blue-green alga that could definitely be identified as this species was obtained from only two soils, but a form very closely resembling it was obtained from two others and may be merely a cultural form of the same species. In the first of these two forms the young colonies were spherical or irregularly elongated, consisting of filaments densely woven together and surrounded by a definite mucous sheath which gradually became yellowishbrown in colour. Later the colonies expanded to form flat and somewhat diffuse strata of more loosely entwined filaments. The vegetative cells were spherical or shortly barrel-shaped and 4 to $4.5 \mu$ broad; but heterocysts were never formed in the cultures, and the spores were rather smaller than is typical for the species, being only 5.5 to $7 \mu$ broad by 6.5 to Io $\mu$ long.

In the second form the general features of the colonies were very similar to those of the first, but the vegetative cells were shortly barrelshaped and 5 to $6 \mu$ broad, while such few heterocysts as were formed in the cultures were exceedingly small, being only 4 to $5 \mu$ in diameter. This reduction in size and frequency of the heterocysts appears, however, to be a fairly common character in cultural forms, and therefore too much importance cannot be attached to it. The spores occurred in large masses and were oval or subspherical, about 6 to $9 \mu$ in diameter. This is the first time that the species has been recorded from Great Britain.

8. Nostoc commune, Vaucher (Text-fig. 4).

Forms of this species were found in three arable soils. In the first form (A) the vegetative cells were barrel-shaped, 4 to $6 \mu$ in diameter, and the heterocysts subspherical and about $6.5 \mu$ in diameter. Spores were 
formed in long chains; they were oval, 4.5 to $7 \mu$ broad by 6 to $7.5 \mu$ long, with smooth colourless walls.

The second form (B), though by its mode of growth and general characters obviously belonging to the same species, differed a little in its dimensions. The vegetative cells were mostly nearly spherical, 4.5 to $5.5 \mu$ in diameter; the heterocysts were somewhat reduced in size, being only 4.5 to $6 \mu$ in diameter, and two or sometimes three were frequently found in series. The spores were oval, and might have their long axis placed either longitudinally or transversely; the walls were smooth and colourless, the breadth 7 to $8 \mu$, and the length Io to I I $\mu$. It is impossible to say from the evidence obtained which form of spore is to be regarded as more typical of the species; form (A) was observed in the cultures of two samples, while form (B) was found only in one, but it is quite possible that (B) represents a later stage of development than $(\mathrm{A})$, though, on the other hand, the small size of the heterocysts in (B) rather indicates that it may be a somewhat abnormal form due to cultural conditions.

9. Nostoc sphaeroides, Kuetz.

A blue-green alga appeared in two of the cultures which agreed more nearly with this species than with any other, and was probably only a cultural form of it. The young colonies were globular, consisting of filaments very closely entwined together and with a close gelatinous envelope. The vegetative cells were shortly barrel-shaped or nearly spherical and 5 to $7 \mu$ in diameter. The ends of the filaments were somewhat attenuated, and the terminal cells longer in proportion to their diameter. Heterocysts were not produced in the cultures, but spores were formed in long chains; they were subspherical or spherical, Io to I $3 \mu$ in diameter, and frequently embedded in a wide and somewhat diffuse mucous sheath. At maturity the sporewall acquired a golden-brown colour, but was never observed to become rough, as has been described for this species. It is possible, however, that this variation may be the effect of cultural conditions, since it has been observed that in the alga Trochiscia aspera, (Reinsch) Hansg., there is a great tendency in cultures for the cell-wall to lose its characteristic external ornamentation. This species has not previously been recorded from the British Islands.

\section{Iо. Nostoc minutum, Desmaz. (Text-fig. 6).}

This interesting little species was found in the cultures of only one sample of soil, but its presence there is all the more noteworthy since it was observed, for the first time on record, to produce spores. The colonies were extremely small and rather irregular in shape, consisting of closely coiled filaments embedded in a definite colourless mucous envelope. The vegetative cells were barrel-shaped, about $2.5 \mu$ broad, and the end cell of the filament was conical. The heterocysts were subspherical, and somewhat variable in size; the majority were 3.5 to $4.5 \mu$ in diameter, but 
occasional heterocysts were found whose diameter was as much as $6 \mu$. The spores were formed in series and were oval with smooth pale-yellow walls ; they were 4.5 to $5 \mu$ broad and 6 to $7 \mu$ long.

I I. Nodularia Harveyana, (Thwaites) Thuret.

The form of this alga, which appeared in four of the samples, very closely resembled that already described from the old stored soils from the Rothamsted Experimental Station, ${ }^{1}$ but was somewhat larger.

The vegetative cells were barrel-shaped, about 4 to $6 \mu$ broad and about half as long. Heterocysts were completely absent, and the spores were sub-spherical and about $8 \mu$ in diameter, or oval and about $9 \mu$ broad by I I to ${ }_{1} 5 \mu$ long, usually about $13 \mu$. There was frequently a distinct mucous sheath surrounding the filament.

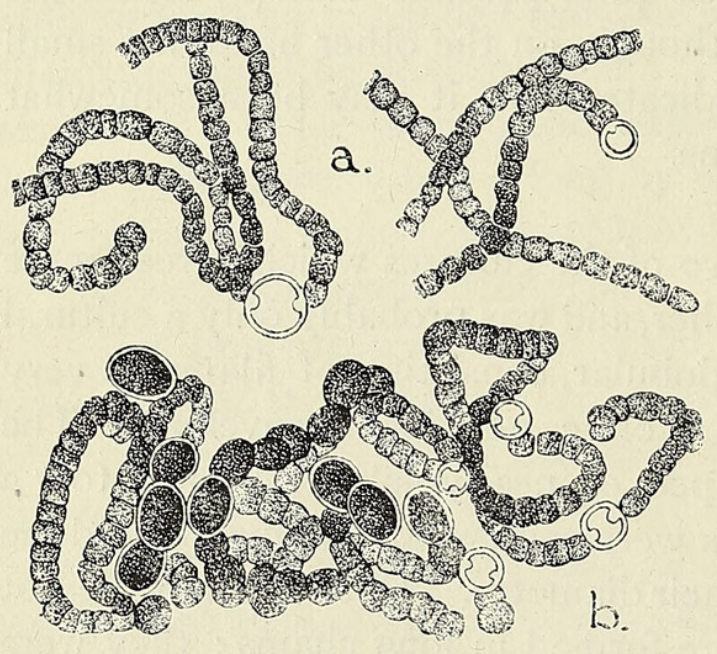

Text-ric. 6. Nostoc minutum, Desmaz. $a$. , vegetative filaments; $b$., spore-formation $\times 825$.

I2. Anabaena variabilis, Kuetz.

This species occurred only in one soil-sample, and is recorded here for the first time from the British Islands. The vegetative cells were barrel-shaped, 4.5 to $6 \mu$ broad, and usually shorter than broad, with slight constrictions between the cells. The heterocysts were spherical or subspherical and 6.5 to $7 \mu$ in diameter. The spores were 7 to $9.5 \mu$ broad and 8 to ${ }^{5} 5 \mu$ long, with smooth yellowish-brown walls; they grew in series, but were to be found sometimes separated
heterocysts, so that the form in the from and sometimes adjacent to the heterocysts, so that the form in the cultures was not exactly typical in this respect.

13. Anabaena inaequalis, (Kuetz.) Born. et Flah., forma.

A somewhat large form of this alga was found in five of the soils. The filaments were almost straight and parallel and were usually loosely entwined to form an extensive stratum. The vegetative cells were shortly barrel-shaped, 5 to $6 \mu$ broad, and about $4 \mu$ long, with slight constrictions between the cells. The filaments gradually tapered towards the end, and the end cell was rounded. The heterocysts were spherical and 6.5 to $8 \mu$ in diameter; and the spores were cylindrical, 8 to $9 \mu$ broad, and 14 to $18 \mu$ long, with smooth yellowish walls. The spores were formed singly or in series of two, three, or as many as six, either adjacent to or apart from the heterocysts. This alga, though differing in dimensions from the typical form, agrees so much more nearly with it than with any other described species that it can only be regarded as a form of this species.

\footnotetext{
1 Bristol, B. M. : loc. cit., I9I9.
} 


\section{English Soils : an Important Factor in Soil Biology. 63}

14. Anabaena sphaerica, Born. et Flah.

In the cultures of two of the soils a blue-green alga appeared which resembled this species more nearly than any other and is probably a form of it, somewhat larger than is typical.

The vegetative cells were 5 to $6 \mu$ or even as much as $8 \mu$ broad, and shortly barrel-shaped. The heterocysts were spherical, 7 to $8.5 \mu$ broad or smaller in young filaments. The spores grew in series on one side of the heterocysts, and had a smooth yellowish-brown wall; they were oval and about Io to I $2 \mu$ broad by I I to I9 $\mu$ long when ripe. This species has not previously been recorded from the British Islands.

I5. Anabaena oscillarioides, Born., var. terrestris, Bristol, forma minor.

This alga occurred in five of the soil samples, but it has already been fully described and figured elsewhere, ${ }^{1}$ hence no further particulars need be given here.

16. Anabaena sp.?

In the cultures of three of the soils an Anabaena was found which, owing to its imperfect development, could not be identified with any of the described species. The vegetative cells were barrel-shaped, 5 to $6 \mu$ in diameter and usually about $4 \mu$ long, though they might be rather longer than broad, and a thin mucous sheath could sometimes be seen surrounding the filament, the terminal cell of which was conical.

Heterocysts were numerous throughout the length of the filament, and were yellowish in colour and subspherical, about $8 \mu$ in diameter, or even occasionally up to $9.5 \mu$. The spores were formed apart from the heterocysts, either singly or in short series of two or three, and when fully ripe appeared to be oval-cylindrical and about II to $12 \mu$ broad by about $27 \mu$ long, with a smooth brownish spore-wall. There was, however, so much variation in the size of the spores that it was impossible to decide which species the form most closely resembled.

17. Cylindrospermum majus, Kuetz.

This alga was found in two soil-samples, and except for the somewhat small size of the spores was quite typical of the species. The vegetative cells were 3.5 to $4 \mu$ broad and 4 to $5 \mu$ long; the heterocysts elongated, about $5 \cdot 5$ to $6 \mu$ broad and $6 \cdot 5$ to Io $\mu$ long; and the spores solitary, with a papillose, dark greenish-brown wall, about I I to I $2 \mu$ broad and $\mathrm{I} 8$ to $22 \mu$ long.

I8. Cylindrospermum licheniforme, (Bory) Kuetz.

This species was found in the cultures of four soils. Vegetative filaments were only rarely seen, and when found the cells appeared to be somewhat large for the species, about 4.5 to $5 \mu$ in diameter and a little longer than broad. The very characteristic spores, I I to I $4 \mu$ broad and 24 to $3^{6} \mu$ long, with their dark red-brown walls and truncate apices, left no

1 Bristol, B. M.: loc. cit., I919. 
doubt, however, as to the identity of the alga. The heterocysts were usually oval, 5 to $6 \mu$ broad by $7 \cdot 5$ to $8 \cdot 5 \mu$ long, but occasionally they were subspherical, about 6 to $7 \cdot 5 \mu$ in diameter.

19. Cylindrospermum muscicola, Kuetz. (Text-fig. $7 \mathrm{~B})$.

In two of the soils a blue-green alga was found which agreed very nearly with this species, though it differed in certain respects. The vegetative cells were 3.5 to $4 \mu$ broad, but were either equal in length or somewhat shorter than broad; one or two conspicuous clear granules were observable in each cell. The heterocysts were oval and mostly 4 to $5 \mu$ broad and 5 to $8.5 \mu$ long, though they might be longer, while the spores were cylindrical-oval, 9 to $10.5 \mu$ broad and 17.5 to $24 \mu$ long, with smooth golden-brown walls.

At $b$ in Text-fig. $7, \mathrm{~B}$, is shown an abnormal filament in which the spore had begun to develop at a little distance from the heterocyst instead of adjacent to it. The species is here recorded for the first time from Great Britain.

20. Cylindrospermum marchicum, Lemm., forma temue, n.f.

In Text-fig. $\%, \mathrm{~A}$, is figured a blue-green alga very closely resembling C. marchicum in all its general characters, but differing from it considerably in point of size; this form was observed in the cultures of only one soil. The vegetative cells were cylindrical, $\mathrm{I} \cdot 5$ to $2 \mu \mathrm{broad}$ and 3.5 to $6 \mu$ long,

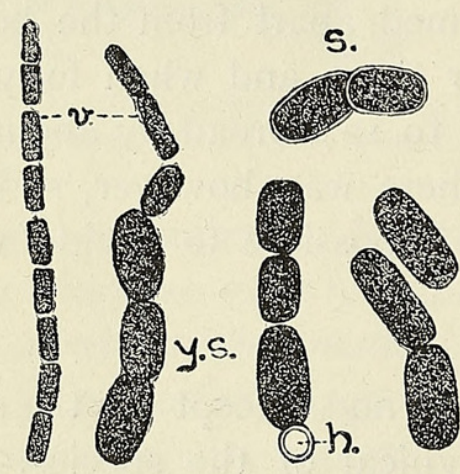

A.

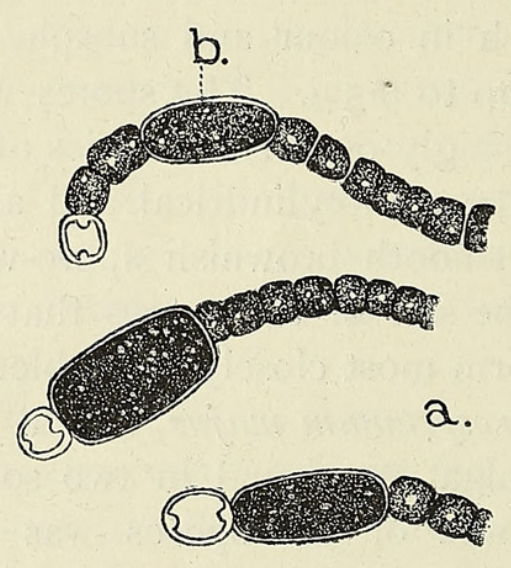

B.

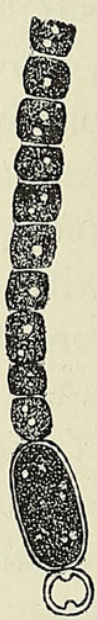

TeXT-Fig. \%. A. Cylindrospermum marchacum, Lemm., forma temue, n.f. h., heterocyst ; s., ripe spores; y.s., young spores in series; v., vegetative cells. в. Cylindrospermum muscicola, Kuetz. a., typical filaments in different stages of spore-formation; $b$, spore formed in an irregular position. $\times 825$.

with conspicuous constrictions between the cells; the apical cell of the filament was conical. Only very few heterocysts were observed, but they were subspherical, about $2.5 \mu$ broad and $3 \mu$ long. The spores were cylindrical, with smooth colourless walls, and 4 to $4.5 \mu$ broad by 9 to II $\mu$ long; they grew in series of three or four together. The extremely elongated vegetative cells and the seriate spores with colourless walls 
make it very probable that this alga is only a small form of $C$. marchicum, Lemm., a species not previously known to occur in this country.

21. Plectonema Battersii, Gomont.

The soil-form of this alga, which was observed in the cultures of no less than thirteen soil-samples, produced flat expanded strata of a dark brownish-green or black colour on the sides of the culture-vessels, consisting of numerous long filaments entwined together and repeatedly branched. The false branches were produced singly or in pairs, and were very slightly narrower than the main filaments and somewhat tapering towards the end; the filaments were 2.5 to $3 \mu$ broad and the cells considerably shorter than broad, with slight constrictions between them ; the end cell was rounded. The cell-contents were homogeneous and pale blue-green.

22. Scytonema javanicum, (Kuetz.) Bornet.

The alga which has been identified under this name was found in two soils only, but in a third soil germinating spores of a similar form were found which never completely developed, and it is probable that they were early stages of growth of the same species. The filaments were agglutinated together and the sheaths were thin, becoming deep yellow; they were usually about $\mathrm{I} 2 \mu$ in breadth. The vegetative cells were usually 9 to Io $\mu$ broad and from 5 to $8 \mu$ long. The heterocysts were brownish and hemispherical at the bases of the filaments, or compressed interstitially, but there was every indication in the cultures that the alga in question had not reached its mature form, and it is possible that at a later stage of development the heterocysts would obtain a more constant shape. The false branches were observed to grow singly and in pairs. This species has not previously been recorded from the British Islands.

\section{Bacillarieae.}

I. Navicula borealis, Ehr. (Text-fig. $8, \mathrm{I}$ and 2).

This species was observed in nine soils, and was one of the largest diatoms growing in the cultures. The form found was exactly typical of the species, but somewhat small, being only 40 to $44 \mu$ long by $8.5 \mu$ broad. There were 6 costae in Io $\mu$. The raphe was bent in the same direction on both sides of the median nodule and at the terminal nodules.

2. Navicula Balfouriana, Grun. (Text-fig. 8, 3-5).

The diatom that has been identified as this species agreed almost exactly with that figured under the same name in Schmidt's 'Atlas der Diatomaceen-Kunde', Heft 79, Tafel 313, Figs. 29-3I. The costae were continuous along the whole length of the valve, and converged slightly towards the middle; there were usually 10 costae in $10 \mu$, rarely II or I2, and the valve was oval, 18 to $24 \mu$ in length by 5 to $6 \mu$ in breadth. The raphe was not bent in the same direction on both sides of the median 
nodule, however, but appeared to be quite straight. This form occurred in thirteen soil-samples.

3. Navicula Brebissonii, Kuetz., var. diminuta (Text-fig. 8, I0-I2).

This diatom was also found in thirteen soil-samples. The valves were narrowly elliptical, about I9 to $24 \mu$ long and 4.5 to $5 \mu$ broad, with Io to II costae in $10 \mu$. The costae were mainly divergent and did not reach to the raphe; they were interrupted opposite the median nodule by a wide space; those nearer the middle were usually shorter than the rest. The raphe appeared to be quite straight. This form differed from the one originally described in that the central costae were not converging as a rule, but the agreement was so close in all other respects that it seems best to include it in the same variety.

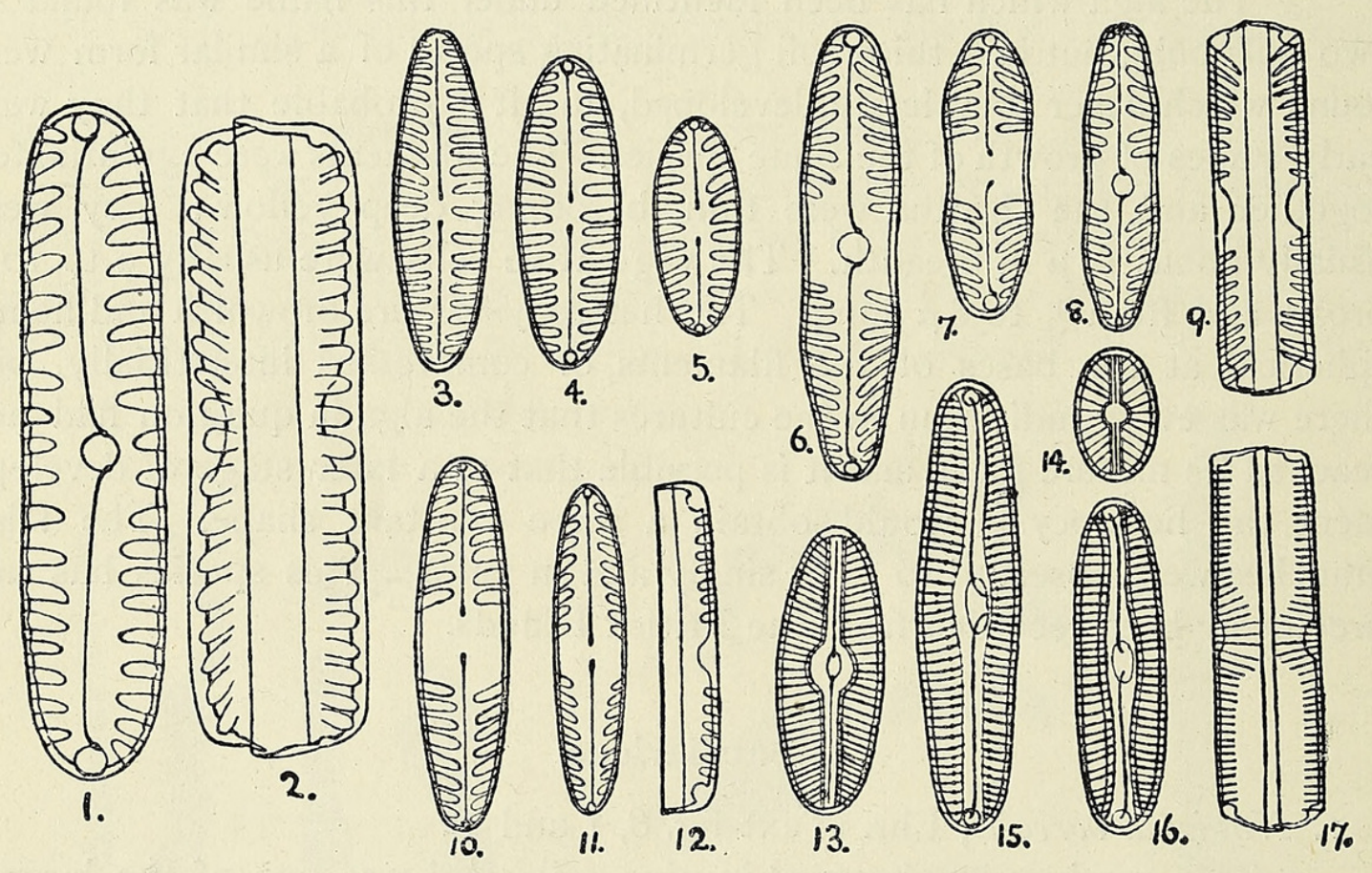

Text-FIg. 8. Soil-diatoms I. I and 2, Navicula borealis, Ehr.; 3-5, N. Balfouriana, Grun.; 6-9, $N$. intermedia, Lagerst.; I0-12, N. Brebissonii, Kuetz., var. diminuta, Van H.; 13, $N$. elliptica, Kuetz., var. oblongella, Naeg.; 14, $N$. elliptica, var. minima, Van H. ; I5-I $7, N$. terricola, n. sp. Figs. I-I $4, \times 1435$; figs. $15^{-1} \%, x$ I 7 I 5 .

\section{Navicula intermedia, Lagerst. (Text-fig. 8, 6-9).}

Petersen has figured a diatom which he considers to be a form of this species (loc. cit., p. 293, Fig. I9) obtained from three Danish soils. A diatom almost exactly resembling Petersen's form has appeared in the cultures of four soil-samples in the present work, and evidently belongs. to the same species, though no previous record has been made of its existence in this country. The valves are slightly constricted in the middle and have somewhat capitate apices; they vary in length from $I 7$ to $27 \mu$, and in 
breadth from 4.5 to $6 \mu$. The costae are convergent towards the middle and divergent towards the apices, and are interrupted by a wide space opposite the central nodule; there are about Io to II striations in $10 \mu$. The raphe is bent in the same direction on both sides of the central nodule and at the terminal nodules.

5. Navicula elliptica, Kuetz.

(a) var. oblongella, Naeg. (Text-fig. 8, I3).

A form appeared in the cultures of one of the soils which agreed more nearly with this variety than with any other described form, and which certainly seemed to be very closely allied to it. The valves were oblongelliptical, about $\mathrm{I} 7 \mu$ long and $6.5 \mu$ broad, with an elongated hyaline area on both sides of the raphe swelling out into a conspicuous circular area around the median nodule, which was oval in shape.

The striations were gradually radiating from the central nodule, about 20 in $10 \mu$, and were interrupted near the raphe by a longitudinal furrow which was exactly parallel to the edge of the hyaline area.

(b) var. minima, Van H. (Text-fig. 8, I4).

A small oval diatom, rarely more than $8 \mu$ long, with a hyaline area and longitudinal furrow exactly similar to that of the above form, was found in two soils. The striations were radiating and about $I 7$ to $I 8$ in $10 \mu$.

6. Navicula terricola, n. sp. (Text-fig. 8, 15-17).

In one of the soils a diatom was found which resembled $N$. elliptica, var. oblongella, very closely, but which differed from it both in the more oblong form of the valve and in the character of the raphe. The length of the valve varied from 16.5 to $22.5 \mu$, and the breadth from 4.5 to $5 \mu$. The striations were slightly curved, almost perpendicular to the raphe near the median nodule and somewhat divergent towards the apices; there were about 21 to 25 in $10 \mu$. The raphe was not straight, but the two halves were slightly sigmoid. The median nodule was oval and the terminal nodules circular. The raphe was surrounded by a conspicuous elongated hyaline area which was gradually dilated around the median nodule and towards the apices. The striations appeared to be interrupted near the raphe by a longitudinal furrow parallel to the edge of the hyaline area. No species has previously been described of which this diatom might be a form, hence it seems most satisfactory to regard it as a new species, nearly related to $N$. elliptica. The following is a diagnosis of the species: Valva linearielliptica, apicibus rotundis, media parte interdum nonnihil inflata. Rapha citra ultraque medium nodulum leviter sigmoidea, zona circumdata conspicua elongata hyalina circa nodulum atque apices versus dilatata. Striae leviter flexae, raphae media parte fere perpendiculares apices versus nonnihil divergentes, sulcis duobus ad zonae hyalinae margines parallele interruptae.

Valvae 16.5 to $22.5 \mu$ longae, 4.5 to $5 \mu$ latae, striae 21 to 25 in $10 \mu$. $H a b$. in solo culto Harborne (Birmingham). 
7. Navicula (§Diploneis) hyalina, Donk., var. minima, n. var. (Text-fig. 9, I8-2I).

An extremely minute diatom, which appeared, so far as it was possible to make out the details of its structure, to be a reduced form of $N$. hyalina, Donk., was found in two of the cultures. The valves were extremely delicate, about I I to I $3.5 \mu$ long by 3.5 to $4.5 \mu$ broad, and so hyaline that it was extremely difficult to make out the details. The striations were extremely faint and could only be distinguished rarely and with difficulty; they appeared to vary from about 27 to 37 in $10 \mu$. The raphe lay in a furrow which in Text-fig. 9,18 and 19 , is shown to terminate abruptly near the median nodule, and in Text-fig. 9, 2I, to be contracted at the apices. In certain individuals (Text-fig. 9, 18 and I9) there appeared to be a double median nodule, but the frustules were so small that it is probable that this was merely a reduced form of the structure figured for $N$. hyalina, Donk., in Schmidt's 'Atlas', Pl. 70, Figs. 4 and 5 ; the terminal nodules were conspicuous. In all of the frustules there was visible a longitudinal furrow (?) running parallel to the margin of the valve about half-way between the margin and the raphe.

It is quite possible that this minute form may be a new species, but the general resemblance in structure to $N$. hyalina, Donk., makes it more satisfactory to regard it as simply a minute variety of this species.

8. Navicula mutica, Kuetz. (Text-fig. 9, I-7).

This extremely variable diatom was observed in the cultures of seventeen different soil-samples, and appears to be one of the commonest soil-diatoms. A number of different forms were found, of which one (Textfig. 9,5) appeared to be identical with that described by Grunow as $N$. Kotschyi; this distinction seems, however, to be quite unnecessary since the characters of the diatom agreed extremely well with those of $N$. mutica. An interesting feature in this species was the great variation in the size of the puncta which made up the transverse striations. As shown in the figures, they were sometimes exceedingly small (Text-fig. 9, I and 7), but they might be much larger so that only five or six were found in each striation (Text-fig. 9, 2-4). Sometimes the puncta appeared to be arranged in no definite order, but in other individuals they were arranged in more or less regular longitudinal rows on the valve (Text-fig. 9,3 ). In the great majority of frustules there were I 8 to I9 striations in Io $\mu$, but in Text-fig. 9, 2 and 6 , are shown individuals with only 14 to 16 striations in $10 \mu$, the one in Text-fig. 9, 6, being still farther removed from the typical form by the oval shape of the valve.

The breadth of the valve varied from 5 to $7.5 \mu$ and the length from about $10 \mu$ to nearly $30 \mu$.

var. quinquenodis, Del. (Text-fig. 9, 8).

This very characteristic variety of the species was found in four soils, and was observed to have the puncta arranged in very definite longitudinal rows so as to produce a regular pattern on the surface of the valve, as shown 
in the figure. The puncta were of variable size according to their position, the one terminating each striation near the raphe being very small and circular, while most of the others were larger and frequently oval in shape. The valve was Io $\mu$ broad and about $25 \mu$ long, with I 7 striations in IO $\mu$.

9. Navicula Pupula, Kuetz. (Text-fig. 9, 24 and 25).

This diatom, as observed in the cultures of eleven soils, showed a considerable tendency to variation in shape. The valves were elongated and usually swollen opposite the median nodule, with rounded apices (Text-fig.9, $25)$; but sometimes they were narrowly elliptical without any enlargement in the centre (Text-fig. 9, 24). There was a straight hyaline zone surrounding the raphe and swelling out abruptly opposite the median nodule to form a false stauros. The striations were radiating, and varied in number from
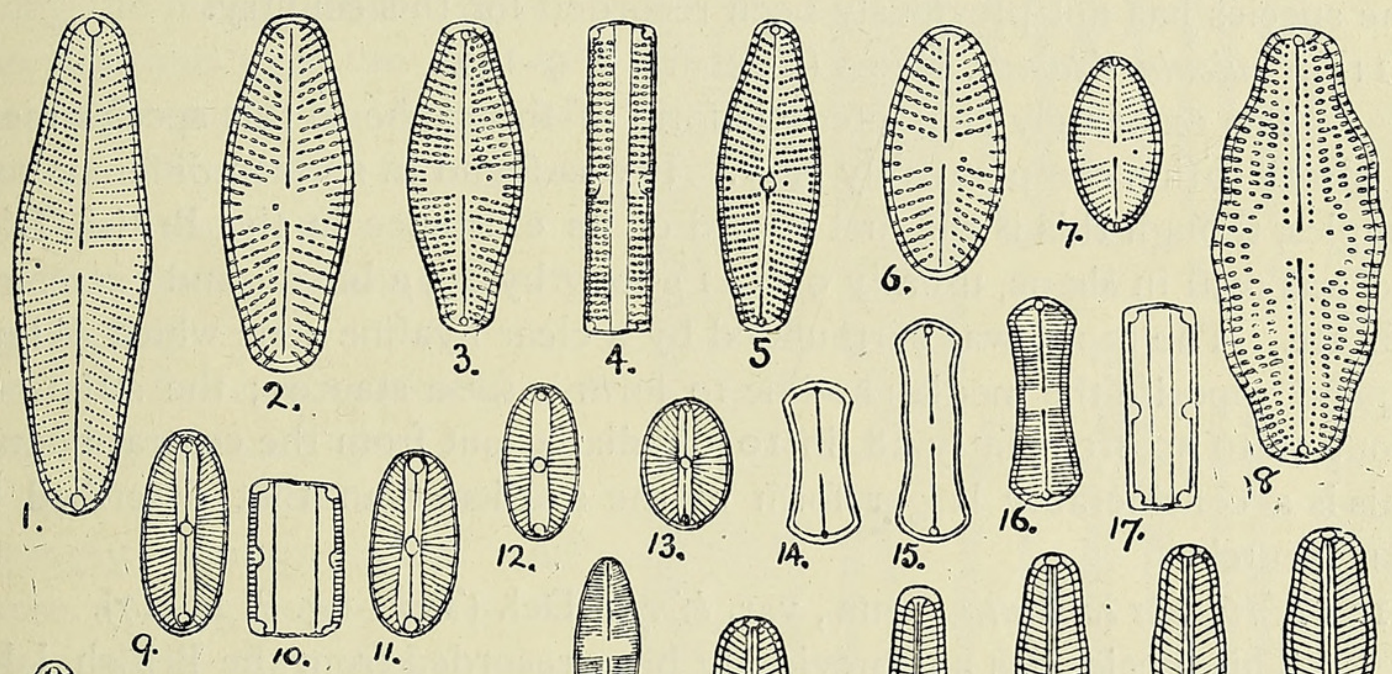

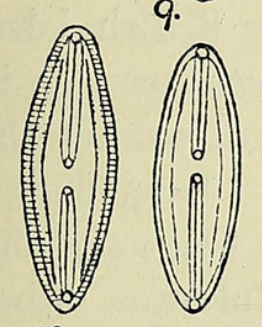

$\cdot 18$.

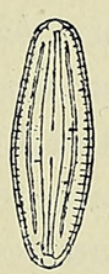

20.

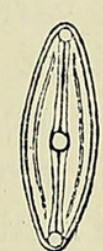

21.

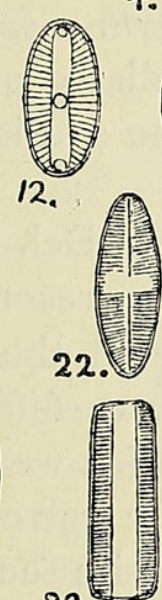

23.
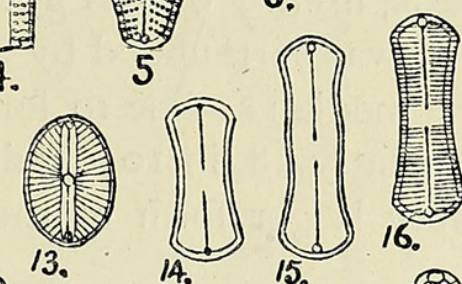

$1 \%$

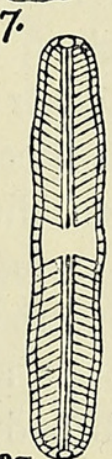

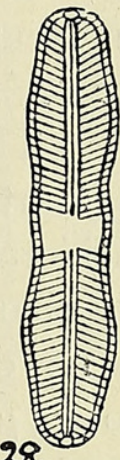

28.

TeXt-FIG. 9. Soil diatoms II. I-7, Navicula mutica, Kuetz. formae, 5 possibly $N$ Kotschyi, Grun. ; 8, N. mutica, var. quinquenodis, Del. ; 9-1 3, N. Atomus, Naeg.; I 4-1 7, N. contenta, Grun., var. biceps, Del.; $18-2 \mathrm{I}, N$. hyalina, Donk., var. minima, $\mathrm{n}_{\mathrm{f}}$ var. (transverse striations doubtful); 22 and $23, N$. exilissima, Grum.; 24 and $25, N$. Pupula, Kuetz. and formae ; 26-8, N. Pupula, var. undulata, n. var. Figs. I-I 7 and $22-8, \times 1435$; figs. I $8-21, \times$ I 7 I 5 .

20 to 24 in $10 \mu$. The terminal nodules were enlarged sideways, but not to the extent that is figured in Cleve and Grunow's 'Die arctischen Diatomeen', Taf. II, Fig. 53 ; the valves were about I9 to $2 \mathrm{I} \mu$ long and 4 to $4.5 \mu$ broad. var. undulata, n. var. (Text-fig. 9, 26-28).

In two of the soils containing N. Pupula, Kuetz., a second form was observed in considerable quantity which differed from the latter in its somewhat larger size, 23 to $25 \mu$ long by 4 to $5 \mu$ broad, and in the shape of the valves. These were oblong with obtuse rounded ends and undulating 
sides; the number of undulations varied, in different individuals, being either two (Text-fig. 9,26) or three (Text-fig. 9,27 and 28). The striations were usually 22 to 24 in Io $\mu$, rarely about I9. In all other respects this diatom agreed with the above species, but the general configuration of the valves was so characteristic that it seemed best to regard it as a special variety, under the name undulata.

Io. Navicula exilissima, Grun. (Text-fig. 9, 22-23).

The markings on this minute diatom, found in two soils, were very difficult to see, but there were about $4 \mathrm{I}$ or 42 striations in $10 \mu$. The valves were Io to II $\mu$ long by about $3.5 \mu$ broad, and elliptical in shape with somewhat pointed rounded ends. The striations were interrupted in the middle, producing a false stauros, and did not quite extend to the raphe. The species has not previously been recorded for this country.

I I. Navicula Atomus, Naeg. (Text-fig. 9, 9-13).

The extremely characteristic form of the raphe in this species made its identification comparatively easy. It was found in sixteen different soilsamples, though this is the first record of its existence in the British Isles, and was oval in shape, usually 9 to I I $\mu$ long by $4.5 \mu$ broad, and extremely delicate. The raphe was surrounded by a clear hyaline zone which did not expand opposite the median nodule to form a false stauros; the striations, about 26 to 30 , frequently 28 , in $10 \mu$, radiated out from the central nodule. This is a considerably larger form of the species than that described by Van Heurck.

I2. Navicula contenta, Grun., var. biceps, Del. (Text-fig. 9, I4-I 7).

This species has not previously been recorded from the British Isles, yet fourteen different soil-samples yielded the variety biceps, usually in considerable quantity. The markings were difficult to make out, but the very characteristic form of the valves, which were united into long chains, left no doubt as to their identity. The valves were 9 to $12 \mu$ long and 3 to $3.5 \mu$ broad; while the swelling opposite the median nodule was either absent or feebly developed. There appeared to be about $3^{8}$ striations in Io $\mu$, with a gap in the middle producing a false stauros, but in the majority of cases it was impossible to see this. The siliceous wall was very thick in comparison with other diatoms of the same size.

I3. Hantzschia amphioxys, (Ehr.) Grun. (Text-fig. 10, I and 2).

The forms of this ubiquitous species which occurred in the cultures were usually small, about 30 to $40 \mu$ in length by 6.5 to $7 \mu$ in breadth, but occasionally larger forms were observed, even up to $60 \mu$ in length. In the larger form (Text-fig. 10, I) there were 7 carinal points in $10 \mu$ and about 16 to I7 striations, but in the smaller forms the carinal points were more numerous, frequently 8 to 9 and sometimes even 10 in $10 \mu$, while there were about 20 striations in $10 \mu$. In each case the two median carinal points were somewhat widely separated and a rudimentary nodule could be seen between them. 
14. Nitzschia obtusa, W. Sm., var. scalpelliformis, Grun. (Text-fig. 10, 7).

A small form of this diatom was found in one of the soils. The length of the valves was only about $45 \mu$, but they were abruptly sigmoid and showed at the middle of their length a distinct inflexion. At this point there was a rudimentary nodule lying between the two median carinal points, which were somewhat separated from one another. There were 7.5 carinal points in $10 \mu$ and 26 striations.

15. Nitzschia Palea, (Kuetz.) W. Sm. (Text-fig. 10, 8-10).

This diatom occurred in the cultures of two soils. The valves were linear-lanceolate with capitate apices, and I I-I 2 carinal points in Io $\mu$, distributed regularly along the margin of the valve; the striations were too faint to be made out. The length of the valves was about 29 to $33 \mu$, and the breadth about $4 \mu$.

var. fonticola, Grun. (Textfig. 10, I I).

A diatom very closely resembling this variety was found in one soil. The valves had strongly capitate apices and there were 15 carinal points in Io $\mu$, while their length was about $I 5 \mu$ and breadth $3.5 \mu$; the striations could not be made out clearly. The valves, however, seemed to be slightly sigmoid, but this character, taken in conjunction with the others, does not seem sufficient to justify the separation of this form from the above variety.
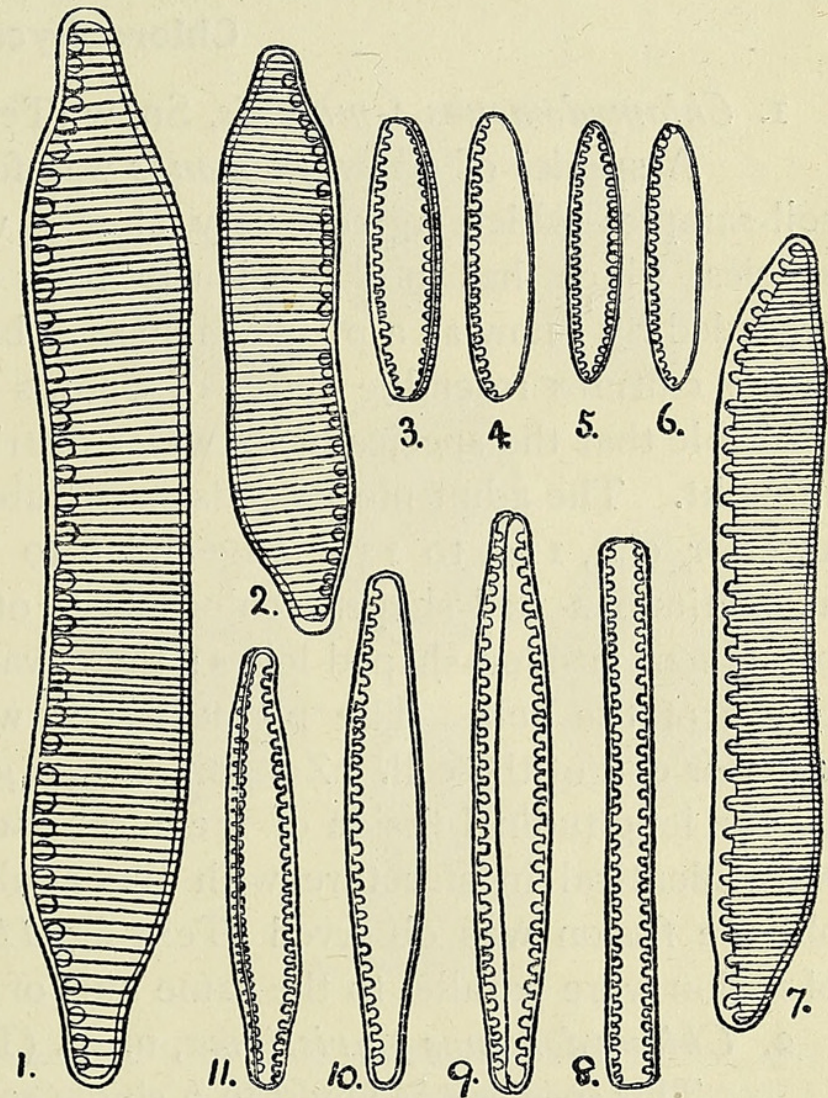

TEXT-FIG. 10. Soil-diatoms III. I and 2, Hantzschia amphioxys, (Ehr.) Grun.; 3-6, Nilzschia inconspicua, Grun.; 7, Nitzschia obtusa, (W. Sm.) var. scalpelliformis, Grun.; 8-Io, Nitzschia Palea, (Kuetz.) W. Sm.; II, Nitzschia Palea, var. fonticola, Grun. All figs. $\times 1435$.

I6. Nitzschia inconspicua, Grun. (Text-fig. 10, 3-6).

A number of very minute forms of Nitzschia, never exceeding $16 \mu$ in length, were found in six of the soils, and though not in exact agreement with $N$. inconspicua, Grun., they should probably be regarded as forms of this species.

The form most nearly in agreement with the description of this species (Text-fig. 10, 3 and 4) was lanceolate with rounded ends and had I 3 to I 4 carinal points in Io $\mu$; the striations were too faint to be seen. The valves were ${ }_{5}$ to $16 \mu$ long and about $4 \mu$ broad. 
A second form (Text-fig. 10,5 and 6) had more linear valves with abruptly tapering rounded apices, and was about $I_{4}$ to $I_{5} \mu$ in length by $3 \mu$ in breadth. There were 15 to 16 carinal points in ${ }_{*} I 0 \mu$ and the striations were too indistinct to be determined.

Both of these forms differ in the number of carinal points from that originally described for the species, but the agreement is so close in other respects that it seems advisable to regard them merely as variable forms of the same species. No previoous record has been made of its occurrence in the British Islands.

\section{Chlorophycae.}

I. Chlamydomonas communis, Snow (Text-fig. 11, I-7).

A species of Chlamydomonas was found in the cultures of five of the soil-samples which agreed very closely with $C$. communis, Snow. This species, which has not previously been recorded for this country, was regarded by Snow as a plankton-species, but the characters of the form seen in the cultures resemble those of Snow's species so closely that it seems probable that the species has a wider distribution than has previously been thought. The adult motile cells were subcylindrical or oval with a pointed anterior end, II. 5 to I $3 \mu$ long and 6 to $7 \mu$ broad, with a thin wall and a continuous bell-shaped chloroplast often raised into more or less prominent cushion-shaped lobes; there was a single large pyrenoid in the centre of the cell. The pigment-spot was inconspicuous and near the anterior end of the cell. Zoogonidia, $4.5 \mu$ broad by $9 \mu$ long, were formed by the longitudinal fission of the mother-cell contents into four parts, and were identical in structure with the adult cells. Very rarely a slightly oblique fission was observed (Text-fig. 11, 7), but in this case both planes of fission were parallel to the same axis of the cell.

2. Chlamydomonas pluristigma, n. sp. (Text-fig. 11, 8-14).

This species was found in a single soil only, but its characters differed considerably from those of any previously described species. The adult cells were oval, with usually a pointed anterior end ; they were 13 to $16 \mu$ long by 9.5 to II $\mu$ broad and possessed a comparatively thick cell-wall. The chloroplast was bell-shaped and lined practically the whole cell-wall except at the anterior end, but it was occasionally perforated (Text-fig. 11, 9 and 10) and the inner surface was frequently raised into cushion-shaped lobes. There was a single large pyrenoid near the centre of the cell, and two or three pigment-spots variously disposed in the cell, one near the anterior end being much larger than the rest. Zoogonidia, $7 \mu$ broad by I $2 \mu$ long, were formed by one oblique and one transverse division of the contents, and were similar to the adult cells.

The following is a diagnosis of the species: Zoogonidiorum tegumentum satis crassum, apice in papillam hyalinam provectum. Cellulae ovales vel 
ovoideae, I 3 -I $6 \mu$ longae, $9 \cdot 5$-I I $\mu$ latae, ciliis binis circa $\mathrm{I} \frac{1}{2}$-plo longioribus praeditae; stigmatibus 2 vel 3 , disciformibus, varie dispositis. Chlorophorum ampullaceum in lobos pulviniformes intus projectum, nonnunquam perforatum, uno magno pyrenoide media parte instructum.

Propagatio fit divisione cellularum matricalium, altera obliqua altera transversa, in 4 zoogonidia.

$H a b$. in solo culto, Sedgley (Staffs.).
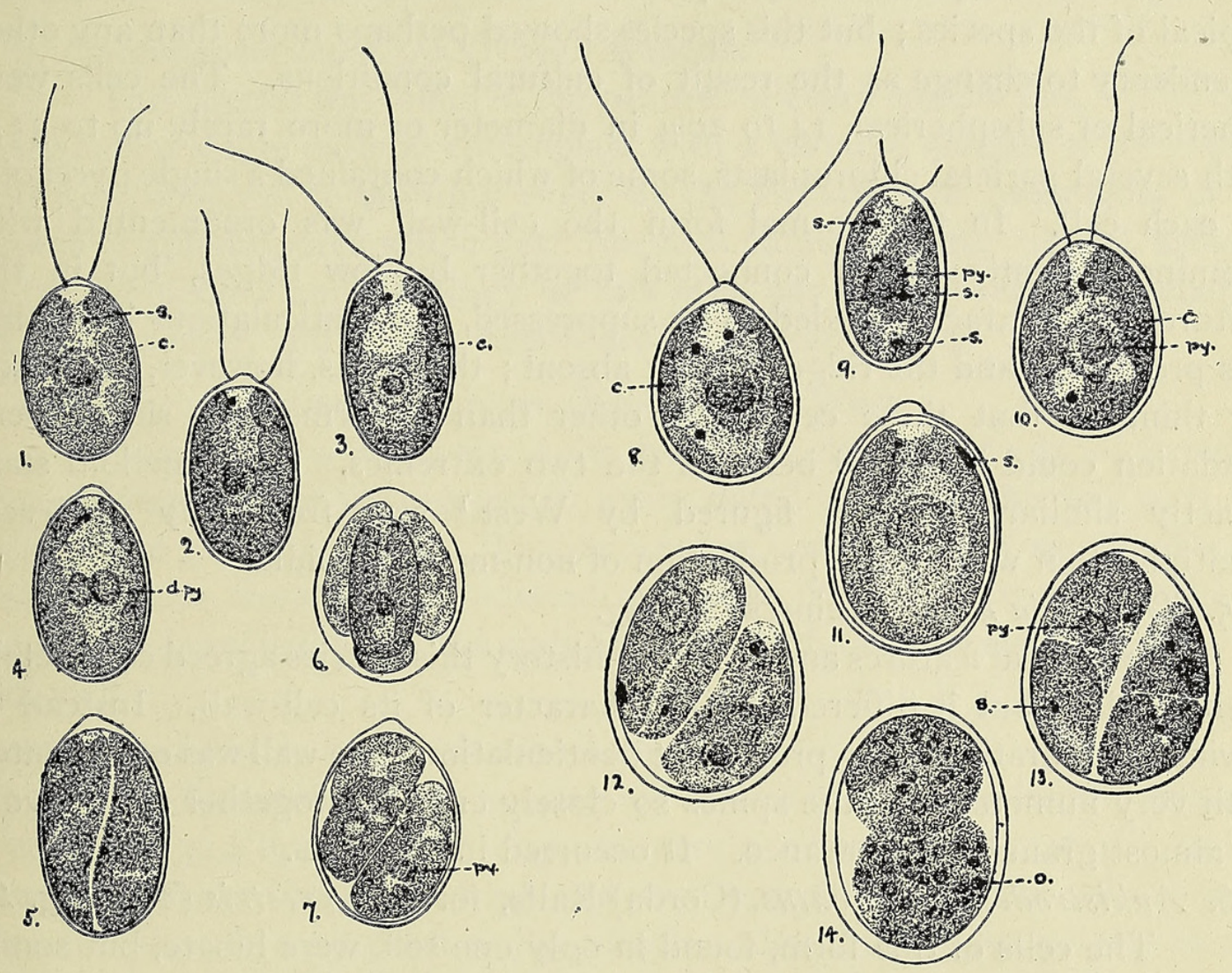

TeXT-FIG. 11. I-7, Chlamydomonas communis, Snow ; I-3, motile vegetative cells ; 4 , resting cell in which division is about to take place; 5 and 6 , longitudinal fission into four zoogonidia ; 7 , oblique fission; $c_{\text {., }}$ chloroplast ; $p y$, pyrenoid ; $d . p y$., dividing pyrenoid; s., pigment-spot; 0. , oil globules; 8-14, Chlamydomonas phiristigma, n. sp. ; 8 and 9, motile cells with three pigment-spots; Io, ditto with two pigment-spots and perforated chloroplast; II, resting cell with two pigment spots ; I 2, oblique fission of cell into two, followed by I 3 , transverse fission into four ; 14 , transverse fission of cell. $\times$ Circ. 1430 .

\section{Coccomyxa Solorinae, Chod., forma.}

In seven of the soil-samples a species of Coccomyxa appeared which agreed more clearly with $C$. Solorinae than with any other described species, but which differed from it in the relative length and breadth of the cells. The cells were oval with rounded or more rarely pointed ends, 6 to $7 \mu$ long by 3 to $3.5 \mu$ broad, and contained a single parietal chloroplast but no pyrenoid. The division of the cell took place at first in an almost transverse plane, but this later became oblique, and the daughter-cells were liberated by the dissolution of the mother-cell wall to form a thin mucilaginous 
envelope in which the young cells remained embedded for some time. In some cases a second division took place before the separation of the young cells, so as to produce groups of four cells enclosed in a common mucilaginous envelope.

This species has not previously been recorded for the British Islands.

4. Trochiscia aspera, (Reinsch) Hansg.

This very widely distributed species was obtained from thirty-four different soil-samples. In many cases the form observed was exactly typical of the species; but this species showed perhaps more than any other a tendency to change as the result of cultural conditions. The cells were spherical or subspherical, 14 to $20 \mu$ in diameter or more rarely up to $33 \mu$, with several parietal chloroplasts, some of which contained a single pyrenoid, in each cell. In the normal form the cell-wall was ornamented with prominent denticulations connected together by low ridges, but in the cultures this character tended to be suppressed, the denticulations becoming less prominent and the ridges almost absent ; there was, however, no reason for thinking that these cells were other than abnormalities, since every gradation could be found between the two extremes. A palmelloid state exactly similar to that figured by West $^{1}$ was frequently observed. Multiplication was by the production of non-motile gonidia.

5. Trochiscia hirta, (Reinsch) Hansg.

In general features and in its life-history this species agreed completely with the last, but it differed in the character of its cell-wall. Instead of having comparatively few prominent denticulations, the wall was ornamented with very numerous minute spines so closely crowded together as to give it an almost granular appearance. It occurred in two soils.

6. Ankistrodesmus falcatus, (Corda) Ralfs, forma terrestris (Text-fig. 2).

The cells of this form, found in only one soil, were lunate, but somewhat narrow, with acute apices. They were 2 to $2.5 \mu$ broad by about $18 \mu$ long, and contained a single chloroplast, usually devoid of a pyrenoid but very occasionally containing one. Multiplication was observed by the production of four or eight autospores which, on the gelatinization of the mother-cell wall, usually remained loosely attached together by one end (Text-fig. 2, $d$ ). The further production of autospores in the same way gradually gave rise to the formation of loose and somewhat irregular colonies, as shown in Text-fig. $2, e$.

7. Dactylococcus bicaudatus, A. Br.

This species was found in one soil. The cells were lunate with greatly prolonged apices, and contained a single rather small chloroplast devoid of a pyrenoid. The length of the cells was 20 to $25 \mu$, and the breadth 3.5 to $5 \mu$. Multiplication was observed to occur by the production of four autospores.

1 West, G. S. : British Freshwater Algae. Cam. Biol. Series, 1904, Fig. 82, F. 
8. Dactylococcus dispar, W. and G. S. West.

This curious form was observed in the cultures of one soil. The cells varied considerably in shape, being either lunate or somewhat distended and irregular. The two extremities of the cells were unequally developed, one often being rounded and the other acute or acuminate and sometimes bent, but there were no prolonged apices as in the last species. The cells were I 3 to $19 \mu$ long and 2.5 to $6 \mu$ broad, with a parietal chloroplast but no pyrenoid. Multiplication took place by the formation of four autospores.

9. Chlorococcum humicola, (Naeg.) Rabenh.

This species was found in the cultures of every soil but one. The cells contained a single parietal chloroplast with a variable number of pyrenoids, and were observed to multiply either by the formation of zoogonidia or by means of aplanospores which gave rise to a palmella-state. A full account of the life-history and cytology of this alga has been given in a separate paper, ${ }^{1}$ however, and further details are unnecessary here.

I0. Chlorochytrium paradoxum, (Klebs) G. S. West.

This alga has also been fully described elsewhere. ${ }^{2}$ It occurred in three different soils and agreed in every detail of its life-history with the description given by Klebs. The chloroplast consisted of a small spherical axial portion from which radiated outwards in every direction variously lobed and branched arms, the ends of which flattened themselves against the cell-wall.

II. Vaucheria hamata, (Vauch.) Lyngb.

The filaments of this species, which was identifiable in only one soil, were 35 to $39 \mu$ broad. The oogonia were produced singly on the end of lateral branches about $65 \mu$ long, and were subspherical, about $5^{6} \mu$ long by $62 \mu$ broad, with very thick walls. Each antheridium grew on the end of a filament branching out from the lower part of the oogonial filament and was about $\mathrm{I} 8 \mu$ in diameter and strongly curved.

The dimensions of this form are somewhat small for the species in every respect, but the mode of growth and general characters leave no doubt as to its identity.

12. Vaucheria sp.?

In four other soils vegetative filaments of Vaucheria were observed, but in none of them were reproductive organs to be found, and consequently identification was impossible. In two cases the filaments almost exactly resembled those of the last species, but in the others they were usually wider, up to $60 \mu$ in diameter.

1 Bristol, B. M. : On the Life-history and Cytology of Chlorococcum humicola, (Naeg.) Rabenh. Journ. Linn. Soc., Bot., vol. xliv, July, 1919.

${ }^{2}$ Bristol, B. M.: A Synopsis of the Genus Chlorochytrium, Cohn. Journ. Linn. Soc., Bot. (inédit). 


\section{I3. Ulothrix subtilis, Kuetz.}

The normal form of this species appeared in the cultures of five soils. The cells were 4 to $5 \mu$ broad and about the same length. After some time in the cultures the filaments were observed to break up into fragments consisting of a dozen or more cells, a character common to practically all of the filamentous forms growing in the cultures.

var. variabilis, (Kuetz.) Kirchn.

This variety of the species occurred much more frequently than the normal form, having been observed in twenty-seven soils. The cells were usually 8 to $9 \mu$ broad and varied in length from $6 \mu$ to about $17 \mu$. There was a single parietal chloroplast extending practically the whole length of the cell and about two-thirds of the way round, and containing as a rule a single large pyrenoid in which the separate starch-plates could frequently be seen. In the winter months, however, the pyrenoid sometimes was not visible. After some time the filaments were observed to break up into

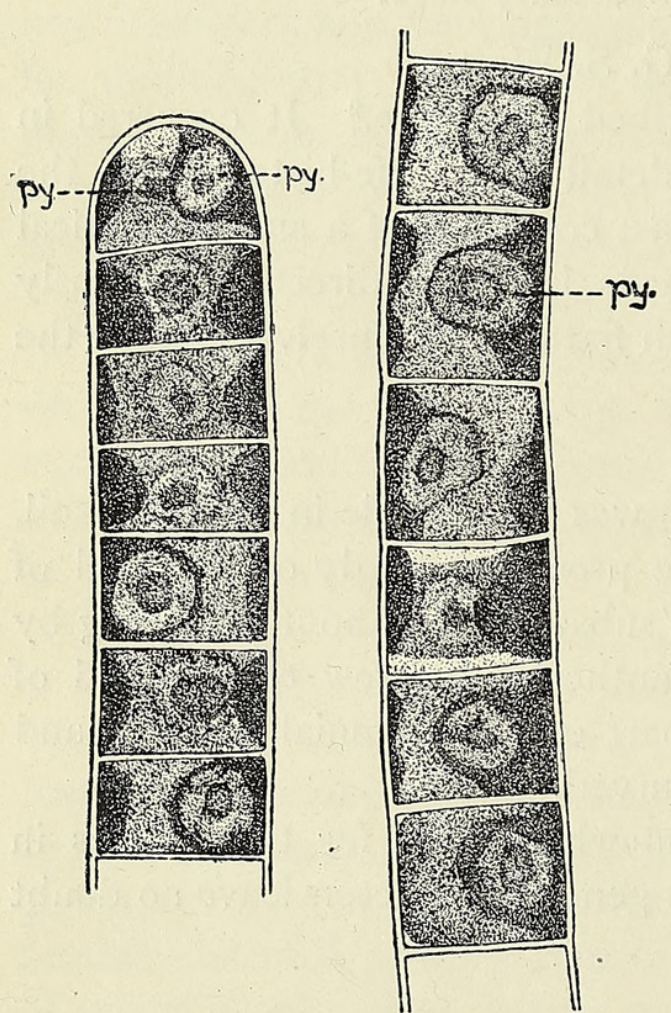

TEXT-FIG. 12. Ulothrix tenuissima, Kuetz.; $p y .$, pyrenoid. $\times 825$. fragments containing a comparatively small number of cells; this was effected by the rounding off of the end walls of two adjacent cells.

I4. Ulothrix tenuissima, Kuetz. (Text-fig. 12).

In one of the soils a species of Ulothrix was observed which differed from $U$. temiissima only in the number of its pyrenoids. The cells were $18 \mu$ broad and Io to $17 \mu$ long, with a firm thin wall. The chloroplast extended practically the whole length of the cell and about three-quarters of the way round the wall, and contained a single large pyrenoid in which it was sometimes possible to detect the separate starch plates. In a single cell only, viz. in the end cell of the filament figured, there were two pyrenoids as has been described by Heering for this species.

I5. Stichococcus bacillaris, Naeg.

The cultural conditions were such that the filamentous form of this species was very rarely observed, and such filaments as did occur consisted of not more than three cells.

The alga thus entered into a unicellular condition, the cells being rectangular with slightly rounded ends, about 6 to $8 \mu$ long and 2 to $2.5 \mu$ broad, with a parietal chloroplast devoid of a pyrenoid extending over about half of the surface of the cell. The species was found in four soils. 
I6. Stichococcus nitens, (Klebs) =Hormidium nitens, Menegh. em. Klebs.

In the cultures of one of the soils there appeared an alga which agreed in its characters very closely with Hormidium nitens, Menegh. em. Klebs, but the filaments were observed to be arranged more or less parallel to one another to form an expanded stratum, and were often completely disarticulated into single cells. Rarely short filaments were formed consisting of 2 to 4 cells, and sometimes long normal filaments could be observed. This mode of growth is entirely that of a Stichococcus, and its occurrence in a form that has previously been regarded as a species of Hormidium rather helps to indicate that the latter genus is based on somewhat unstable characters. The extraordinary confusion existing among the species of Ulothrix, Hormidium, and Stichococcus makes it wellnigh impossible to distinguish between Hormidium and Ulothrix on the one hand and between Hormidium and Stichococcus on the other ; hence, pending further investiga-

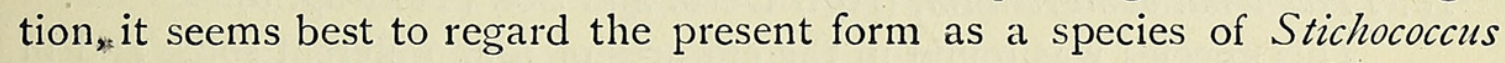
rather than of Hormidium. The cells were 5 to $6 \mu$ broad and 8 to I $5 \mu$ long ${ }_{3}$ frequently about $9 \mu$. The single parietal chloroplast extended usually from end to end of the cell and about two-thirds of the way round, and contained a single pyrenoid, or two in those cells about to divide. Disarticulation of the filaments was effected by the splitting apart and rounding off of the transverse walls of adjacent cells.

17. Gongrosira terricola, n. sp. (Plate II).

This new species of Gongrosira, found in soil-samples from three widely separated localities, differs from all others previously described in its terrestrial habit and in the basal or more rarely intercalary position of its zoogonidangia. In the latter character it most closely resembles $G$. Codiolifera, Chod., in which the zoogonidangia are intercalary in the upstanding filaments; but the absence of a limy incrustation establishes it as separate from this species independently of the position of the zoogonidangia.

The stratum is expanded, and the creeping filaments are closely interwoven to form a pseudo-parenchymatous disc of distended cells. The upstanding filaments are usually comparatively short and tapering with obtuse apices; they are irregularly branched, either in small tufts (Pl. II, Figs. B and G) or with false dichotomy (Figs. D and F). The basal cells are swollen, II to I6 $\mu$ in diameter. Those of the upstanding filaments are subcylindrical or distended, and may be irregular on account of a tendency to branch; they are usually Io to $18 \mu$ long and 6 to $14 \mu$ broad, with a single band-shaped or irregular chloroplast containing usually one pyrenoid, rarely two, or sometimes none. The zoogonidangia are generally basal (Figs. A and H), but more rarely may be intercalary in the upstanding filaments. They are usually subspherical or irregular, 14 to $18 \mu$ in diameter or occasionally less, opening by means of a lateral pore to set free a large number of biciliate zoogonidia. 
The following is a diagnosis of this new species:

G. terricola, in solo culto vigens, stratum expansum efformans; thalli pars inferior e filamentis densis ramosis, cellulis tumidulis subglobosis vel irregularibus constat, pars superior e filamentis erectis fasciculato- vel pseudodichotomo-ramosis apicem versus angustioribus, cellulis subcylindricis tumidulis vel irregularibus. Cellulae inferiores if to i $6 \mu$ crassae, cellulae filamentorum erectorum 6 to I $4 \mu$ latae, Io to $18 \mu$ longae, cellulae apicales obtusae non attenuatae, omnes chromatophoro irregulari parietali, pyrenoidibus singulis (rarissime binis) vel nullo instructae.

Zoogonidangia basalia vel intercalaria subglobosa vel ovoidea, 14 to $18 \mu$ crassa, ore minuto laterali dehiscentia. (Wilts.).

$H a b$. in solo culto Kettering (Northants), Baggeridge (Staffs.), Tisbury

18. Tribonema bombycinum, (Ag.) Derb. and Sol. (Text-fig. 5).

This species was found in the cultures of four different soils, and in most cases was quite typical in character, with slightly tumid cells, 8.5 to $9 \mu$ broad by $I 8$ to $2 I \mu$ long, and cell-walls breaking into $\mathrm{H}$-shaped pieces in the fragmentation of the filament. Multiplication by means of zoogonidia was not observed in the cultures, but aplanospores were formed as described at the end of Section III of this paper.

19. Bumilleria exilis, Klebs. (Text-fig. 1).

This alga, though never previously recorded for the British Islands, was found in forty of the soils, and is evidently a typical soil-species, since it was originally described by Klebs from a very similar habitat. Its appearance in the cultures seemed to be periodic; its growth gradually attained to a maximum during the first eight months of the investigation, and in May, 1916, it was the dominant form present in many of the cultures. From that time onwards it gradually disappeared until in the early months of I9I 7 only a few isolated filaments could be found; while six months later it had again increased in quantity in many of the cultures, though the second maximum never attained to the height of the first.

The cells of the filaments were almost rectangular, with slightly tumid walls, and were usually about $4.5 \mu$ broad. They varied in length from 10 to $15 \mu$, sometimes less, and contained a variable number of small, parietal, yellow-green chloroplasts, four in the shorter cells and 6 to $\mathrm{I} 2$ in the longer ones; starch was never observed in them, but small globules of oil were often present.

Multiplication took place most frequently by a fragmentation of the filament, either through the breaking of the wall of one of the cells into $\mathrm{H}$-shaped pieces (Text-fig. $1, d$ ), or more frequently through the splitting apart of the end walls of two adjacent cells (Text-fig. 1,b), and the consequent formation of knee-bends. In a few cases the early stages of 
zoogonidia-formation were observed, four zoogonidia being produced within a cell, but these were never seen to acquire cilia or to escape from the cell, and it is possible that the cultural conditions were such as to preclude this form of multiplication.

\section{Summary.}

The investigation by means of water-cultures of forty-four samples of soil from widely separated localities has shown that there is a widely distributed ecological plant-formation in cultivated soils consisting of moss protonema and algae. The most important algae in this formation are: Hantzschia amphioxys, (Ehr.) Grun., Trochiscia aspera, (Reinsch) Hansg., Chlorococcum humicola, (Naeg.) Rabenh., Bumilleria exilis, Klebs and to a less degree Ulothrix subtilis, Kuetz., var. variabilis, (Kuetz.) Kirchn. Other species of typical soil-algae occurring somewhat less frequently give rise to smaller plant-associations within this formation.

The total number of species and varieties found in these soils is sixtyfour-20 Bacillarieae, 24 Myxophyceae, and 20 Chlorophyceae. The soilsamples had all been subjected to complete desiccation for 4 to 26 weeks before being placed in the cultures; hence these species could be expected to withstand any period of drought that might occur naturally.

It seems likely that this extensive algal formation must be of considerable economic importance in the biology of the soil.

Six new species or varieties are described, sixteen species already described are newly recorded for the British Islands, and a number of new or interesting stages are depicted in the life-histories of certain species already known, especially in connexion with the germination of the spores of some blue-green algae. The final section of the paper contains a short account of each of the species found in the cultures.

In conclusion, the writer desires to express her thanks to a number of friends who assisted her in making the collection of soil-samples. In particular she wishes to acknowledge her indebtedness to Professor G. S. West for his valuable help, especially in the identification of the species, and for his unfailing encouragement throughout the course of the investigation.

The Botanical Laboratory,

UNIVERSITY OF BIRMINGHAM. 
80 Bristol On the Alga-Flora of some Desiccated Soils.

\section{DESCRIPTION OF PLATE II.}

Illustrating Miss B. M. Bristol's paper on the Alga-Flora of some Desiccated Soils.

\section{All figures $\times 825$.}

A. Part of pseudo-parenchymatous base of thallus, with a single upstanding filament and numerous basal zoogonidangia (b.z.).

B. Part of upstanding filament, showing tufted branching.

C. Ditto, showing intercalary zoogonidangia (i.z.).

D-F. Tapering apical branches, showing false dichotomous branching and irregular chloroplasts.

G. Part of thallus, showing tufted branching and intercalary zoogonidangia opening by a lateral pore.

H. Creeping filaments with basal zoogonidangia.

I. Early stage in formation of zoogonidia. 
Annals of Botany,

Vol.XXXIV,Pl.II.

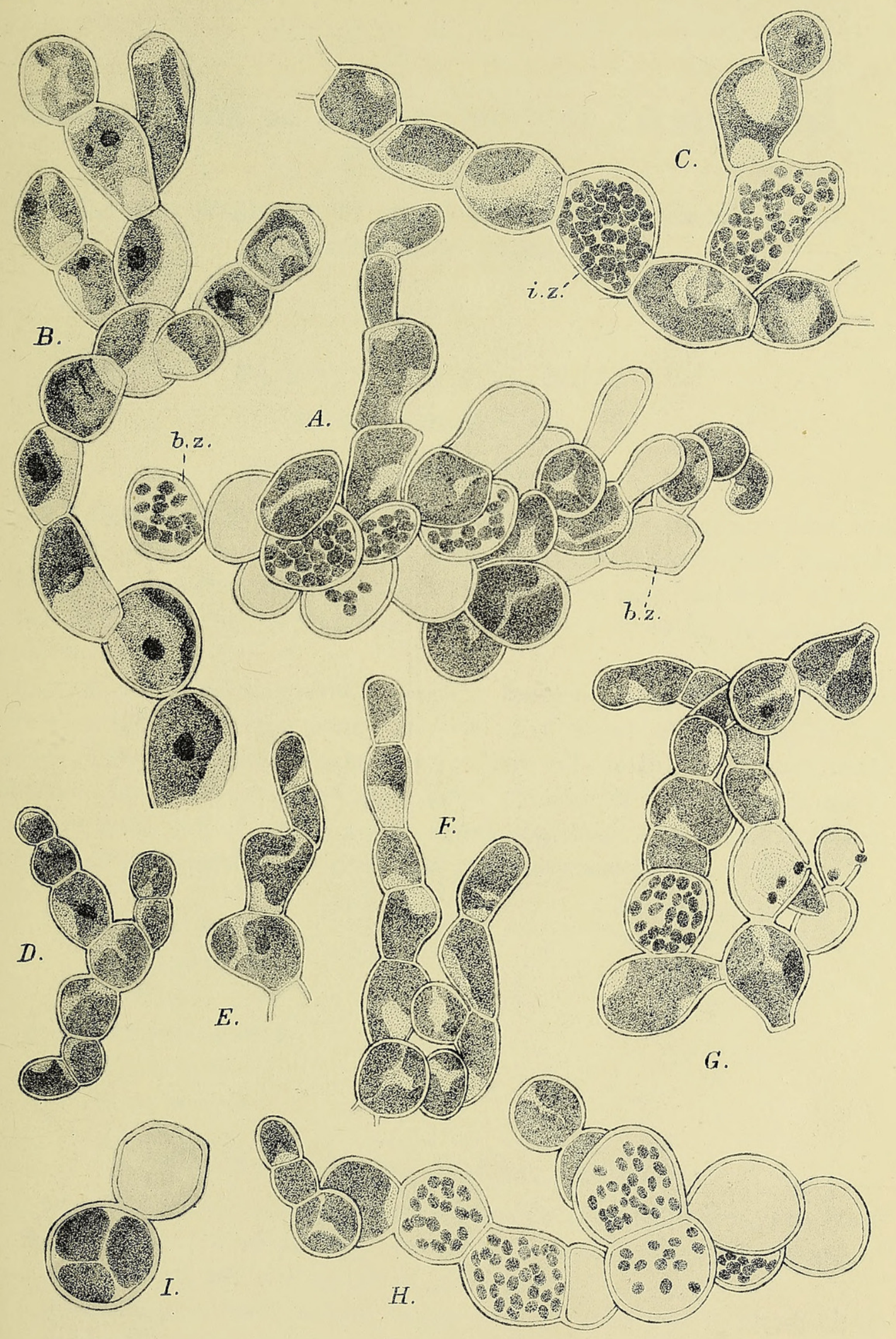

B.M.B. del.

Huth, London.

BRISTOL- GONGROSIRA TERRICOLA, n.sp 


\section{$2 \mathrm{BHL}$ Biodiversity Heritage Library}

Bristol, B. Muriel. 1920. "On the alga-flora of some desiccated English soils: an important factor in soil biology." Annals of botany 34, 35-80.

https://doi.org/10.1093/aob/os-34.1.35.

View This Item Online: https://www.biodiversitylibrary.org/item/236972

DOI: https://doi.org/10.1093/aob/os-34.1.35

Permalink: https://www.biodiversitylibrary.org/partpdf/320274

\section{Holding Institution}

Smithsonian Libraries

\section{Sponsored by}

Biodiversity Heritage Library

\section{Copyright \& Reuse}

Copyright Status: Not in copyright. The BHL knows of no copyright restrictions on this item.

This document was created from content at the Biodiversity Heritage Library, the world's largest open access digital library for biodiversity literature and archives. Visit BHL at https://www.biodiversitylibrary.org. 